This PDF is a selection from an out-of-print volume from the National Bureau of Economic Research

Volume Title: Dividends Under the Income Tax

Volume Author/Editor: Daniel M. Holland

Volume Publisher: Princeton University Press

Volume ISBN: 0-870-14455-3

Volume URL: http://www.nber.org/books/holl62-1

Publication Date: 1962

Chapter Title: Dividend Underreporting on Tax Returns

Chapter Author: Daniel M. Holland

Chapter URL: http://www.nber.org/chapters/c1949

Chapter pages in book: (p. 57 - 109) 
CHAPTER 2

\section{Dividend Underreporting on Tax Returns}

\section{High Fraction of Total Dividends Traced to Tax Returns}

Ir has already been noted that because their distribution is so highly concentrated, a significant proportion of aggregate personal dividend receipts can be traced to tax returns even in those years when the personal income tax did not reach most of the population. Thus, as summarized in Table 15, over the four decades of our study the percentage of total dividends found on taxable returns was never lower than 60 , and most frequently ran over $75 . .^{1}$

Yet a closer look at Table 15 indicates that some of the variations in this coverage ratio are not of the kind one would expect and may therefore be significant. Why, with exemptions lowered, incomes rising, and the number of taxpayers increasing greatly from $194 \mathrm{l}$ on, did the fraction of total dividends traceable to taxable returns decline noticeably?

Although the figures for taxable returns in Table 15 suggest this question, they are not the most germane or convenient for attacking it directly. Therefore, in what follows, the data for all returns will be used-nontaxable as well as taxable-and the data on tax returns and on aggregate dividends will be adjusted to make them comparable. To this end also, the dividends received by fiduciaries and those paid out to their beneficiaries will be handled differently and more precisely than heretofore. ${ }^{2}$ For these reasons, items 4 and 13 of Table 16 below

\footnotetext{
1 The data in Table 15 are from Table 1, and appear here for the reader's convenience.

2 Before 1936, these adjustments were either unnecessary or impossible.
} 
TABLE 15

Aggregate Personal Drvmends and Dividends Reported on Taxable Returns, 1918-1957

(dollars in millions)

\begin{tabular}{|c|c|c|c|}
\hline $\begin{array}{l}\text { Year } \\
\text { (1) }\end{array}$ & $\begin{array}{l}\text { Aggregate } \\
\text { Personal } \\
\text { Dividends } \\
\quad(2)\end{array}$ & $\begin{array}{c}\text { Dividends } \\
\text { on Taxable } \\
\text { Returns } \\
\text { (3) }\end{array}$ & $\begin{array}{c}\text { Col. } 3 \text { as a } \\
\text { Per Cent } \\
\text { of Col. } 2 \\
(4)\end{array}$ \\
\hline 1918 & $\$ 3,518$ & $\$ 2,321$ & $66.0 \%$ \\
\hline 1919 & 2,882 & 2,304 & 79.9 \\
\hline 1920 & 3,211 & 2,549 & 79.4 \\
\hline 1921 & 2,959 & 2,050 & 69.3 \\
\hline 1922 & 3,044 & 2,283 & 75.0 \\
\hline 1923 & 3,837 & 2,689 & 70.1 \\
\hline 1924 & 3,811 & 2,849 & 74.8 \\
\hline 1925 & 4,421 & 3,105 & 70.2 \\
\hline 1926 & 4,721 & 3,533 & 74.8 \\
\hline 1927 & 5,046 & 3,846 & 76.2 \\
\hline 1928 & 5,485 & 4,094 & 74.6 \\
\hline 1929 & 5,813 & 4,317 & 74.3 \\
\hline 1930 & 5,490 & 3,861 & 70.3 \\
\hline 1931 & 4,088 & 2,602 & 63.6 \\
\hline 1932 & 2,565 & 1,640 & 63.9 \\
\hline 1933 & 2,056 & 1,286 & 62.5 \\
\hline 1934 & 2,587 & 1,670 & 64.6 \\
\hline 1935 & 2,863 & 1,906 & 66.6 \\
\hline 1936 & 4,548 & 3,477 & 76.5 \\
\hline 1937 & 4,685 & 3,790 & 60.9 \\
\hline 1938 & 3,187 & 2,481 & 77.8 \\
\hline 1939 & 3,788 & 3,004 & 79.3 \\
\hline 1940 & 4,043 & 3,472 & 85.9 \\
\hline 1941 & 4,458 & 3,962 & 88.9 \\
\hline 1942 & 4,289 & 3,531 & 82.3 \\
\hline 1943 & 4,484 & 3,536 & 78.9 \\
\hline 1944 & 4,673 & 3,669 & 78.5 \\
\hline 1945 & 4,691 & 3,723 & 79.4 \\
\hline 1946 & 5,784 & 4,561 & 78.9 \\
\hline 1947 & 6,521 & 5,297 & 81.2 \\
\hline 1948 & 7,243 & 5,923 & 81.8 \\
\hline 1949 & 7,473 & 6,317 & 84.5 \\
\hline 1950 & 9,208 & 7,544 & 81.9 \\
\hline 1951 & 9,029 & 7,446 & 82.5 \\
\hline 1952 & 8,954 & 7,280 & 81.3 \\
\hline 1953 & 9,225 & 7,208 & 78.1 \\
\hline 1954 & 9,839 & 7,622 & 77.5 \\
\hline 1955 & 11,215 & 8,419 & 75.1 \\
\hline 1956 & 12,132 & 9,427 & 77.7 \\
\hline 1957 & 12,588 & 9,869 & 78.4 \\
\hline
\end{tabular}

Source: Col. 2: Table 1; col. 3: Statistics of Income. 


\section{Dividend Underreporting on Tax Returns}

TABLE 16

Derivation of Dividends Not Accounted for on Tax Returns, 1958

(million dollars)

1. Dividends reported by individuals on tax returns, including dividends received from fiduciaries (estates and trusts) 9,058

Plus

2. Estimated dividends in "other income," $1040 \mathrm{~A}$ returns

Plus 3. Dividends retained by fiduciaries and dividends included in the charitable contributions of fiduciaries

Equals 4. Dividends of individuals and fiduciaries accounted for on tax returns

5. Dividends paid by domestic corporations

6. Intercorporate dividends

7. Dividends received by individuals from abroad 179

Plus

8. Dividends paid to foreigners

9. Dividends received by nonprofit organizations 501

Minus

10. Dividends received by noninsured pension funds

11. Capital gains dividends paid out by investment trusts 327

Minus

Minus

12. Nontaxable dividends

Equals 13. Maximum estimate of dividends reportable by individuals and fiduciaries

Note: Source and methods of estimation appear in the notes to Table 23.

differ, respectively, from the dividends on taxable returns and aggregate personal dividends in Table 15.

The difference between the aggregate amount of specific types of income generated in the productive process and the totals of such types of income traceable to tax returns has been a subject of interested speculation over the years, particularly since the "democratization" of the income tax. The reasons for this interest are obvious: the possible poor record-keeping, faulty memory, and dishonesty of taxpayers and the potential revenue losses of the Federal Government on these counts. Work on this problem has, of course, gone beyond speculation: estimates of the gap have been made. ${ }^{3}$ And additional estimates for

3 Pioneering work has been done by Selma Goldsmith (cf. her "Appraisal of Basic Data for Constructing Income Size Distribution," pt. VI, Studies in Income and Wealth, 13, New York, National Bureau of Economic Research, 1951, and "Relation of Census Income Distribution Statistics to Other Income Data," in An Appraisal 


\section{Dividends Under the Income Tax}

dividends will be set forth in this section. But it is necessary to note at the outset that some measure of speculation and uncertainty will always surround such estimates. The author has essayed this task twice before, and a good deal of the framework and language of this section is taken from these earlier efforts, particularly the more recent of them. ${ }^{4}$ But the estimates that follow, and the conclusions based on them, differ from those in the two earlier efforts, in part because one learns by doing, and in part because one learns from others. Other investigators have noted and corrected errors and oversights in my earlier procedures. ${ }^{5}$

The fact that the estimates change each time they are undertaken and are considerably lower than in my two previous attempts suggests an imprecision which it would be foolish to deny. Undoubtedly there is still an intractable hard core of error. But in my judgment the error is smaller than before, the present estimates are better than those made earlier, and, with appropriate qualifications, conclusions can be drawn from them. Moreover, as will be elaborated below, we are now in a position to judge, under restricted assumptions, whether a "real" change occurred in dividend-reporting propensities from year to year.

This chapter deals with a specific topic in a particular way. These limitations should be stressed. It is a particular concept of underreporting which we seek to estimate, a concept which is several degrees removed from both dishonesty and revenue loss. Part of the job, then, is to make very clear what our measures mean or do not mean, and

of the 1950 Census Income Data, Studies in Income and Wealth, 23, Princeton for NBER, 1958). More recently the Treasury has released estimates of the dividend “gap" for 1955-1959. (See President's Tax Message Along With Principle Statement, Detailed Explanation, and Supporting Exhibits and Documents, Committee on Ways and Means, U.S. House of Representatives, May 3, 1961, p. 143.)

Unpublished estimates generously made available to the author have been undertaken for 1952, 1956, 1958, and 1959 by Stan West, Associate Director of the Department of Research and Statistics of the New York Stock Exchange.

4 See Daniel M. Holland, "Dividend Underreporting on Tax Returns," Journal of Finance, May 1958, pp. 238-260, and idem, "Unreporting of Dividends and Interest on Tax Returns," in Tax Revision Compendium, Committee on Ways and Means, House of Representatives, 1959, Vol. 2, pp. 1397-1438. The estimates of this latter paper were partially revised in testimony given before that Committee on December 8, 1959; see Panel Discussion before the Committee on Ways and Means, House of Representatives, Eighty-Sixth Congress, First Session, p. 768.

5 To the United States Treasury Department's Office of Tax Analysis staff, and to Stan West, and Milton Leontiades, both in the Department of Research and Statistics of the New York Stock Exchange, I am indebted for these corrections and an explanation of how they went about them. Neither they nor any one else but me is responsible for the errors of fact or interpretation that may still remain. 


\section{Dividend Underreporting on Tax Returns}

to provide some idea of the range of error that attaches to them. For it is only in the light of information of this kind that the findings can be interpreted. That is why the procedures and methods of estimating are spelled out in more detailed fashion than might seem necessary; and that is why, also, several estimates have been undertaken where there seemed to be legitimate grounds for alternative approaches.

The general question is the divergence between the total dividends paid out by corporations and the amount of this type of income reported on personal tax returns. This divergence is called the dividend gap which, as we measure it, is made up partly of dividends that were not and did not have to be reported under the revenue laws and partly of dividends that were not reported but legally should have been. As will be argued in greater detail below, while this latter category cannot be precisely broken out, inferences as to its size and growth or decline over time can still be made.

Specifically, this chapter covers three topics: (1) the size of the dividend gap in 1958 and the revenue loss associated with it; (2) changes in the gap over the last twenty-three years; and (3) evidence on the income class distribution of underreporting. It concludes with a note that explains our estimating procedures.

In discussing these topics, we depart from the measure of aggregate dividend receipts used in Table 15 and in Chapter 1-i.e., the dividend component of personal income as estimated by the National Income Division (NID) of the Office of Business Economics of the Department of Commerce-and substitute in its stead data directly from Statistics of Income. Although not important for the broad purposes of Chapter 1 , this distinction is useful for the detailed scrutiny of a residual, which is our main concern in this chapter for a number of reasons. To the best of my understanding, in making their foreign dividend flows estimate the NID at several points used assumptions which involved an overstatement of personal dividend receipts from abroad. This means that in the aggregate individuals (and fiduciaries) are credited with "too much" in the way of pretax dividends. Although this is probably not a serious matter for the national income accounts, for our measure it would tend to overstate the dividend "gap." And since the gap is computed as a residual, this overstatement could be more serious. Moreover, for 1958, a Statistics of Income figure is to be preferred because we can expect the NID 1958 estimate to be revised once more, and it is better to use a consistent procedure for all years. 


\section{Dividend Gap in 1958}

By way of introduction to our data, we first examine dividend underreporting for one year, choosing the most recent year for which the requisite data have been published in detail, 1958. The approach is simple. By adding up various dividend amounts tabulated in Statistics of Income (Volume 1) or estimated therefrom, we obtain an estimate of the amount reported by individuals and fiduciaries on tax returns, called $R$ here. Similarly, by adding to (or in most cases in subtracting from) the dividends paid out by corporations-again as published in Statistics of Income (Volume 2)-a number of categories of dividend flows that go to others than individuals and fiduciaries or that individuals and fiduciaries would not have to report, we arrive at a maximum amount that individuals and fiduciaries could be expected to report on tax returns, called $M$ here. The difference between $M$ and $R$ is the gap, herein designated as $G$.

Table 16 shows the steps in our derivation of the gap. ${ }^{6}$ The first step is to start with dividends received and reported as such by individuals on tax returns (including dividends received by individuals from estates and trusts). The next step is to add the small amount of dividends tabulated under "other income" on form 1040A returns, add also the dividends retained by estates and trusts (fiduciaries) to reach a figure of $\$ 9.4$ billion of dividends of individuals and fiduciaries accounted for on tax returns (line 4). The next nine lines of Table 16 show the derivation of $M$. Here we start with dividends paid out in cash and assets other than own stock by domestic corporations, a total obtained from corporation income tax returns. ${ }^{7}$ But some of this dividend flow took place between corporations and never reached individuals, and this (line 6) must be subtracted. Moreover, individuals

${ }^{6}$ For this purpose we use variant 2 (explained below) which in 1958 differed only slightly from variant 1 .

7 Note then that our derivation of $G$ is not circular. $M$ and $R$ are in effect independent estimates from different statistical sources. The main item in both $M$ and $R$ is a tax return total, but in the one case (line 1 ) it is a total obtained from the personal income tax returns; in the others, the aggregate figure (line 5) comes from corporation income tax returns. Besides assuring that the measure of the gap is not circular, the fact that $M$ and $R$ are independently estimated, and more particularly the fact that their sampling variabilities are independent, permits us to set a confidence interval on the gap (once the sampling variabilities are known). And this, in turn, makes it possible to test for statistically significant changes in the gap from year to year (discussed later in this chapter). 


\section{Dividend Underreporting on Tax Returns}

received dividends from foreign corporations, which should show up on tax returns (line 7). But, on the other hand, the dividends paid by domestic corporations to foreigners would not be included in the data tabulated from personal income tax returns (line 8). Two sets of institutions that hold sizable amounts of stock but are not subject to personal income taxation-nonprofit organizations (universities, foundations, museums, hospitals, and the like) and noninsured pension funds-account for the subtractions of lines 9 and 10. The total on line 5 includes capital gains dividends paid out by investment companies. We know that they are to be reported as capital gains, and we assume they all went to individuals and fiduciaries. Therefore they are subtracted (line 11). Nontaxable dividends are, of course, not reported, and so must be subtracted (line 12). ${ }^{8}$

All these adjustments result in an estimate of $\$ 10.4$ billion for the maximum amount of dividends that could possibly have been reported on individual tax returns (line 15). The difference between this total and the $\$ 9.4$ billion on line 4 (dividends of individuals and fiduciaries accounted for on tax returns) we call the dividend "gap" (line 14). ${ }^{\circ}$

A detailed description of our procedures and the data for each year from 1936 through 1958, arranged as in Table 16, appears in the note at the end of this chapter.

In the main, our interest lies not in the amount of the gap for a single year, but in variations in the gap over time, since this may tell us something about possible changes in dividend-reporting propensities. But before turning to this, the meaning of the gap for 1958 (estimated at around $\$ 1$ billion in Table 16 ) can be analyzed in detail, which will help prevent confusion that might otherwise arise. Also, of course, it is interesting to speculate on what might be the revenue implications of a gap of this size.

8 Three types of dividends fall into this category-liquidating dividends; dividends of public utilities and, to a lesser degree, of real estate companies (primarily because of accelerated amortization and depreciation); and, since 1958, dividends of small business corporations which elected to be taxed as partnerships ("tax option" corporations). The first two categories are considered to be return of capital, not reportable as dividends. The third is included in the total on line 5 , but would be reported along with the rest of each owner's aliquot share of the corporation's earnings and not as dividends.

9 More appropriately, it should be called a dividend "gap," for as our table has already made clear and the discussion in the next few paragraphs to follow will amplify, there are numerous gap measures that could be devised. However, we shall call it the gap, meaning thereby not the only gap but the one we have chosen to use. 


\section{Dividends Under the Income Tax}

The first qualification, which although obvious is frequently overlooked, is that we should not present a single value for the gap but rather a range within which the true gap might fall were it estimated many times from different estimates of its component values. And for this range we could merely state the expectation that the "true" gap would be covered by the interval we set out, in nineteen cases out of twenty, or ninety-nine out of a hundred, etc. For the gap is a random variable and can take on a set of values different from the "true" value because of sampling variability. More precisely, $G$ is a random variable because both $M$ and $R$ are random variables, and the sum (or difference) of random variables is itself a random variable. As noted in going through Table 16, $M$ and $R$ each are the net resultant of subtracting and adding estimated values. Sampling variabilities can be placed around most of these estimated values with some precision. This is because the sampling design of Statistics of Income is known. ${ }^{10}$ Known sampling variabilities exist for the main components of $M$ and $R$. For $R$ we have estimates of the sampling variabilities of dividends reported by individuals and dividends reported by fiduciaries. We also have an estimate of the sampling variability of dividends paid by domestic corporations and intercorporate dividends, which is the main component of $M$. We can go further and assign sampling errors to the remaining components of $M$ and $R$, and since these are almost pure guesses we make them "large." As a matter of fact, the relevant magnitudes are such that, even though $\sigma_{G}^{2}=\sigma_{M}^{2}+\sigma_{R}^{2}{ }^{11}$ it turns out that $\sigma_{R}^{2}$ dominates the results. Therefore, $\sigma_{Q}$ is very close

10 This does not mean that the desired or necessary sampling variability is easily obtainable. The author is grateful to Ernest Engquist of the Internal Revenue Service who gave general counsel and advice on this matter as well as estimates of sampling variabilities of the main components of $M$ and $R$.

${ }^{11} \sigma^{2}=$ variance; $\sigma=$ standard deviation. We have this expression for the variance of the gap because the variance of a sum (or difference) of independently estimated random variables is the sum of the variances. More specifically, our "model" in principle is this:

1. $M=M^{\prime}+\epsilon$, where $M$ is the observed value, $M^{\prime}$ is the true value, and $\epsilon$ is a sampling error with mean 0 and $\sigma^{2}$ given by our sampling variability.

Similarly, we have

2. $R=R^{\prime}+\nu$ and with $G=M-R$

3. $\sigma_{G}^{2}=\sigma_{M}^{2}+\sigma_{R}^{2}=\sigma_{M^{\prime}}^{2}+\sigma_{\epsilon}^{2}+\sigma_{R^{\prime}}^{2}+\sigma_{\nu}^{2}$

However we know that $M^{\prime}$ and $R^{\prime}$ are the true values. Thus each has a $\sigma^{2}=0$.

Therefore we can rewrite (3) simply as:

3. $\sigma_{G}^{2}=\sigma_{\epsilon}^{2}+\sigma_{\nu}^{2}$ and

4. $\sigma_{G}=\sqrt{\sigma_{\epsilon}^{2}+\sigma_{\nu}^{2}}$

Actually, in addition to sampling errors the data reflect biases, i.e., nonrandom errors of measurement. A little more is said about this later. 


\section{Dividend Underreporting on Tax Returns}

to $\sigma_{R}$. For 1958 we estimate $\sigma_{G}$ to have been about $\pm \$ 41$ million. Thus the .99 confidence interval (which is set by a range of about $\pm 21 / 2 \sigma_{G}$ around the measured gap) for the gap would be $\$ 900$ million to $\$ 1.1$ billion. The odds are 99 to 1 that this confidence interval covers the "true" gap, if no bias is present or if biases cancel out.

Now for the second main qualification. The gap, as we define it, is not a direct measure of dishonesty or evasion in the reporting of dividends, nor is it the base to which to apply a marginal rate to estimate the revenue loss due to the failure of taxpayers to report all of their dividends. For, in addition to those dividends that should have been reported but were not, the gap includes the dividend receipts of those persons and estates and trusts who, because their adjusted gross income was below the filing requirement of $\$ 600$, did not have to report for tax purposes..$^{12}$ It is not possible to determine with any precision the amount of this latter category of dividends, but a reasonable estimate would be about $\$ 150$ million. ${ }^{23}$

We conclude, then, that in 1958 between $\$ 750$ and $\$ 950$ million of dividends (the gap of $\$ 1.0$ billion plus or minus $\$ 0.1$ billion minus the estimate of nontaxable dividends of $\$ 150$ million) that should have been reported on tax returns were not.

12 To go from the gap adjusted on this score to the tax base loss involves an additional subtraction-the dividends not reported by persons who had to report but would have been nontaxable anyway.

13 This estimate was arrived at as follows: Dividends received by low-income individuals not required to file returns were estimated at $\$ 107$ million by the U.S. Treasury for 1958 (see source cited in earlier footnote). In addition, some estates and trusts did not have to file tax returns because their income fell below the exemption levels. However, we are not interested in their dividend receipts per se, but only those that went to individuals who did not have to file. For otherwise the dividend receipts of such fiduciaries would show up on the tax returns filed by the individual beneficiaries thereof.

In connection with their work for the National Bureau's Postwar Capital Markets study, Eli Shapiro and Raymond Goldsmith have estimated the assets of fiduciaries not required to file, i.e., with a gross annual income of less than $\$ 600$, as $\$ 6.3$ billion in 1952. They consider this figure to be an overstatement rather than an underestimate. Assuming that stock comprised the same fraction of their assets as it did for the fiduciaries that did file (53.64 per cent), we get a figure of $\$ 3.4$ billion of stockholdings for fiduciaries in this group. Using a yield of 4.76 per cent (the yield implicit in the Shapiro-Goldsmith multiplier of 21 by which dividend flows were capitalized to arrive at stockholdings), we estimate that $\$ 162$ million of dividends were received by fiduciaries not required to file. Since net dividends (i.e., net corporate dividends plus dividends received from individuals abroad minus dividends paid to foreigners) in 1958 were about 30 per cent higher than in 1952, we may estimate that about $\$ 210$ million of dividends were received in 1958 by fiduciaries not required to file. A generous guess is that between $\$ 40$ and $\$ 50$ million went to individuals not required to file. 


\section{Dividends Under the Income Tax}

To go from this figure to the amount of dividends directly related to revenue loss, however, requires some additional adjustments. For some of this underreporting is a venial sin, as far as tax revenue is concerned, since some taxpayers who are required to report their dividends but fail to do so would not be taxed on them anyway, because their exemptions and deductions exceed their adjusted gross income, or because of the exclusion from taxable income of the first $\$ 50$ of dividends (on separate returns) or $\$ 100$ of dividends (on joint returns). Without any firm basis for making these adjustments, it seems safe, i.e., more of an over- than an understatement, to put such dividends at $\$ 100$ million in all. ${ }^{14}$ This would mean an increment to the tax base of between $\$ 650$ and $\$ 850$ million if all unjustified nonreporting of dividends had been corrected in 1958. Using the estimates in Table 21 as a rough guide for the income class distribution of underreported dividends, and applying the marginal rates that follow from such a distribution, provides an estimated gain in income tax revenue falling in the interval (see note at end of this chapter for details). We conclude therefore that in 1958, the revenue loss from dividend underreporting was on the order of $\$ 200$ to $\$ 240$ million.

It may be of interest to place the dividend gap in perspective by comparing dividends with other types of income in this respect. For this purpose, variant 2 of Table 17 is most comparable with estimates for other sources of income. For 1957, we were able to trace 91.5 per cent of dividends to tax returns. This can be compared with the estimated coverage ratios for 1957 of 97 per cent for wages and salaries, 72 per cent for entrepreneurial income (a weighted average of 81 per cent for business and professional proprietors' income and 45 per cent for farm operators' income), and 42 or 63 per cent for interest. ${ }^{15}$ Thus dividends are exceeded only by wages and salaries among the sources

14 In the New York Stock Exchange estimates of the dividend gap prepared by Stan West and Milton Leontiades, dividends received by nonfiling, nontaxable individuals required to file are estimated at $\$ 50$ million. Our estimate is large enough to cover both this and the $\$ 37$ million they estimate for small, nontaxable estates and trusts.

15 The wages and salaries and entrepreneurial income coverage estimates are from C. Harry Kahn, "Coverage of Entrepreneurial Income on Federal Tax Returns," in Tax Revision Compendium, Committee on Ways and Means, House of Representatives, 1959, Vol. 2, pp. 1443 and 1449. The lower interest estimate is from Holland "Unreporting of Dividends and Interest on Tax Returns," in same source, p. 1418; the higher coverage percentage for interest is an estimate of the U.S. Treasury Department and is more detailed and more accurate than mine. It can be found in President's Tax Message, 1961, p. 146. 


\section{Dividend Underreporting on Tax Returns}

of income in tax return coverage. That dividends should have a high coverage ratio is not surprising in view of their concentration in the upper portion of the income distribution. But one would not expect to find the proportion traceable to tax returns to be noticeably higher for wages and salaries than for dividends. This is undoubtedly partly explained by the fact that the tax liability on wages and salaries is withheld at the source.

As a necessary caution in interpreting what follows, we take this opportunity to point out the statistical hazards of our measure of the gap. Even after the gap has been expressed in terms of a confidence interval, it does not embody the "gospel" truth. For the statistical model is really more complicated than described above. In addition to sampling errors, the data also contain nonrandom errors, i.e., biases. All we can do is say that the biases may be large or small; they may cancel out or reinforce one another. (Whatever their size, they do not, of course, affect the variance of the gap.) It is our presumption, or perhaps hope, that they are small, since most of the numerical weight in our estimates comes from items subject to small or no bias, i.e., the items whose sampling variability we know. And we also assume that either they tend to cancel each other out or, if they reinforce each other, being small, the distortion introduced is not great. If these presumptions (or hopes) hold, the gap could be a reasonable approximation of the "truth," both as to level and variations in level for comparisons between years. In all honesty, I see no real basis for determining whether bias seriously affects the meaningfulness of changes in the size of the gap between given periods of time. (Remember, we have already taken account of random errors.) The difference between the values of the gap under variants 2 and 3 is due solely to different estimates of the dividends of nontaxable estates and trusts. In some years the difference between variants 2 and 3 was larger than the sampling errors, which suggests that sources of error other than sampling were important. Yet it is not the mere fact of bias that is damaging. For in comparisons over time a consistent bias is a virtue; absolute levels may be wrong, but meaningful conclusions can be drawn from changes in them if they are consistently wrong. Needless to say, since comparisons over time are undertaken, my judgment is that the bias is not strong enough and inconsistent enough to preclude comparisons over time. 


\section{Changes in Gap over Last Twenty-Three Years}

In addition to determining the present size of the dividend gap, it is also of interest to study the movement of the gap over time. In one sense this is essential since the gap is the residual of two sets of variables both subject to error and results for any one year must be viewed with scepticism. But more than that, by examining the data over a run of years, we can find out whether underreporting has become more or less significant. For if it has tended to dwindle over time, perhaps it is a problem that will correct itself; but if it has grown or remained at about the same level, perhaps more positive action than heretofore taken will be necessary to correct it. Also, an examination of the trends in underreporting may provide some insight into the factors that affect it. Has underreporting increased when the tax saving from not reporting increased (that is to say, when tax rates rose), and decreased as taxes became less severe? Although our data are not precise enough to provide an unequivocal answer to this question, they will, nevertheless, permit some inferences to be drawn.

With these considerations in mind, estimates of the dividend gap were prepared for 1936-1958. The results, summarized in Table 17, enable us to examine variations and trends in the size and relative importance of the gap. However, before turning to a discussion of these results, some general remarks are in order.

Although the gap is a residual made up both of dividends that should have been reported but were not and dividends that were not reported because they did not have to be, and although it is impossible to pinpoint these two components, nevertheless the data permit inferences about the zealousness of stockholders in reporting their dividend income. Thus, for example, if between two years the income above which filing was required was lowered and the gap (particularly in relative terms) rose, one can infer an increase in intentional underreporting (assuming, as seems reasonable, that memory lapse and poor records are stable factors not subject to sharp variations over short periods). For, other things being equal, the gap should have declined.

This same conclusion would follow if, with exemptions and filing requirements unchanged, dividends payments increased and the gap remained relatively as large or grew larger. ${ }^{16}$ But such inferences

16 In both this and the previous statement it is assumed that there were no startling changes from year to year in the way stock ownership and dividend receipts 


\section{Dividend Underreporting on Tax Returns}

TABLE 17

Drvidend GaP, 1936-1958

\begin{tabular}{|c|c|c|c|c|c|c|}
\hline \multirow[b]{2}{*}{ Year } & \multicolumn{3}{|c|}{ Absolute Gap (million dollars) } & \multicolumn{3}{|c|}{ Relative Gap (per cent) a } \\
\hline & Variant 1 & Variant 2 & Variant 3 & Variant 1 & Variant 2 & Variant 3 \\
\hline 1936 & 519 & 272 & - & 12.0 & 6.3 & - \\
\hline 1937 & 604 & 356 & - & 13.7 & 8.1 & - \\
\hline 1938 & 325 & 150 & - & 10.9 & 5.0 & - \\
\hline 1939 & 440 & 244 & - & 12.4 & 6.9 & - \\
\hline 1940 & 130 & -34 & -24 & 3.5 & -0.9 & -0.6 \\
\hline 1941 & 74 & -107 & -188 & 1.8 & -2.6 & -4.6 \\
\hline 1942 & 412 & 141 & 299 & 10.4 & 3.6 & 7.6 \\
\hline 1943 & 638 & 363 & 464 & 15.6 & 8.9 & 11.3 \\
\hline 1944 & $670^{\mathrm{b}}$ & $400^{b}$ & 575 & 15.6 & 9.3 & 13.4 \\
\hline 1945 & 596 & $377^{b}$ & 371 & 13.9 & 8.8 & 8.6 \\
\hline 1946 & 836 & 498 & 527 & 15.8 & 9.4 & 10.0 \\
\hline 1947 & 721 & 400 & 490 & 12.1 & 6.7 & 8.2 \\
\hline 1948 & $628^{b}$ & 260 & 434 & 9.5 & 3.9 & 6.6 \\
\hline 1949 & $646^{b}$ & $165^{b}$ & 349 & 9.5 & 2.4 & 5.1 \\
\hline 1950 & 863 & 489 & 607 & 10.3 & 5.9 & 7.3 \\
\hline 1951 & $735^{b}$ & $404^{b}$ & 548 & 9.0 & 5.0 & 6.7 \\
\hline 1952 & $782^{b}$ & $523^{b}$ & - & 9.7 & 6.5 & - \\
\hline 1953 & 1,126 & 779 & - & 13.5 & 9.3 & - \\
\hline 1954 & 971 & $934 \mathrm{~b}$ & - & 11.3 & 10.9 & - \\
\hline 1955 & 1,368 & 1,326 & - & 14.0 & 13.5 & - \\
\hline 1956 & $1,202^{b}$ & $1,154^{b}$ & - & 11.6 & 11.1 & - \\
\hline 1957 & 961 & 906 & - & 9.0 & 8.5 & - \\
\hline 1958 & $1,051^{b}$ & $993^{\mathrm{b}}$ & - & 10.0 & 9.5 & - \\
\hline
\end{tabular}

Note: All changes in the gap for variants 1 and 2 between one year and the next are significant at the .01 level except where indicated by b. (Variant 3 was not tested for significant annual changes.) The test used is described in the note on procedures at the end of this chapter.

a The relative gap is the absolute gap computed as a percentage of the maximum estimate of dividends reportable by individual and fiduciaries (line 14 of Table 26).

b Change in gap between this and preceding year not significant at 0.1 level.

should be drawn only after due regard to the range of error that characterizes our estimates. Any pronounced changes shown up by the data are probably real, but the data will not support refined arguments based on relatively slight differences. In what follows, therefore,

are divided up within the family unit. This is a reasonable assumption, for it would have paid those rationally seeking to minimize taxes to make such arrangements before the start of our period. 


\section{Dividends Under the Income Tax}

we shall be concerned only with sharp and clear differences; small variations that cannot be dissociated from the imprecision of the estimates are neglected. To be more specific, in Table 17 the difference between 1943 and 1944 is not significant at the .01 level; the difference between 1941 and 1942 clearly is.

The presentation of three different estimates of the dividend gap in Table 17 is due to three things: legitimate differences in concept, the change in the way dividends were tabulated in Statistics of Income because of the tax relief provided this income share in the Internal Revenue Code of 1954, and my good fortune in having the advice of Dr. Joseph Pechman. Both the change in the tax law and a judgment that it was one sensible way of defining the gap explain the use of variant 1; Dr. Pechman's insight led to the development of variant 2, as an alternative to my original estimate, now called variant 3 . The variants ${ }^{17}$ differ among themselves only in the way in which the dividend component of the income of estates and trusts (fiduciaries) is accounted for. In variant 1 the dividend component of individuals' income from estates and trusts 18 and the dividends retained by fiduciaries are added to individuals' dividends reported as such. The sum of the dividend components of individuals' income from estates and trusts and the dividends retained by fiduciaries is a narrower base than that used in variants 2 and 3 , as indicated by the bigger dividend gaps provided by variant 1 . But for comparisons over time, it is not necessarily the level of the gap, but rather changes in the level, that is of prime importance. Moreover, variant 1 has its advantages: it is conceptually more appropriate for a comparison over time that includes the years 1954-1958, and its estimates of fiduciary dividends, while more narrowly based, are probably more accurate than those of variants 2 and 3 from 1940 through $1951 . .^{19}$ Variants 2 and 3 account for the dividends of estates and trusts on the basis of what these entities per se, whether

17 Details on the values used in their derivation appear in the note at the end of this chapter.

18 From 1954 on, to get the benefit of the exclusion and credit, dividends received from estates and trusts were broken out and reported and tabulated as dividends. For the years 1936-1953 we had to estimate the dividend component of what was reported under the heading of income from estates and trusts.

19 These are the years in which dividends of nontaxable estates and trusts were not tabulated and had to be estimated for variants 2 and 3 . But in all years individuals reported income from estates and trusts whether the estate or trust was taxable or not, and while the dividend component of this income, as noted above, had to be estimated up through 1953 for variant 1 , this estimate is probably less subject to error. 


\section{Dividend Underreporting on Tax Returns}

taxable or not, reported on the returns they filed. Because they account for the dividends when received by the fiduciaries rather than when some beneficiary of the trust reports having received them, variants 2 and 3 will show larger dividends associated with fiduciary income than variant 1 . Variants 2 and 3 will, and variant 1 will not, include dividends paid out by fiduciaries to individuals not required to report and to tax-exempt organizations. Since they will also include dividends paid out by fiduciaries to individuals who, although required to report, fail to do so, variants 2 and 3 overstate the degree of reporting. Also, to the extent that estates and trusts not required to report for tax purposes pay out dividends to individuals who report them on their tax returns, variant 1 includes something not covered by 2 and 3. The failure of variant 1 to include dividends paid by fiduciaries to tax-exempt organizations is trivial. I estimate it for 1958, for example, at under $\$ 60$ million; in earlier years it was presumably less.

The difference between variants 2 and 3 originates in the method of estimating the dividends of nontaxable fiduciaries in the years in which only the data for taxable fiduciaries were published-1936, 1937, and 1940-1951. For variant 2, dividends of nontaxable fiduciaries were estimated by using the ratios (or interpolating between them) of fiduciary dividends to total personal dividends in the years for which both taxable and nontaxable fiduciary data were tabulated-1939, 1952, 1954, and 1956. For variant 3, it was the ratio of taxable fiduciary dividends to dividends of nontaxable fiduciaries in 1939 and 1952 that was used as the basis of estimation. In developing these estimates, I had initially used variant 3, but at the suggestion of Joseph Pechman, tried the method incorporated in variant 2. While there is no way of establishing which of these two variants, 2 or 3, is more nearly correct, the variant 2 values appear more "reasonable," and I shall, therefore, refer to them and the variant 1 values in discussing changes in the dividend gap. In any event, the differences among all three annual measures concern levels of the gap and not its pattern of movement over time. When it comes to year-to-year changes (not levels), variants 1 and 2 tend to give the same picture, as can be seen from Chart 3. By way of comparison, the coverage percentages for wages and salaries are also plotted on the chart.20

20 The percentage of wages and salaries accounted for on tax returns comes from C. Harry Kahn, "Coverage of Entrepreneurial Income on Federal Tax Returns," in Tax Revision Compendium, Vol. 2, p. 1443. 


\section{Dividends Under the Income Tax}

With this run of estimates numerous comparisons are open to us, and we start with a comparison that in one particular aspect is the least equivocal. In 1937, 1938, and 1939 and again in 1952, 1954, and

\section{CHART 3}

Percentage of Dividends and Wages and Salaries Accounted for on Tax Returns, 1936-1958

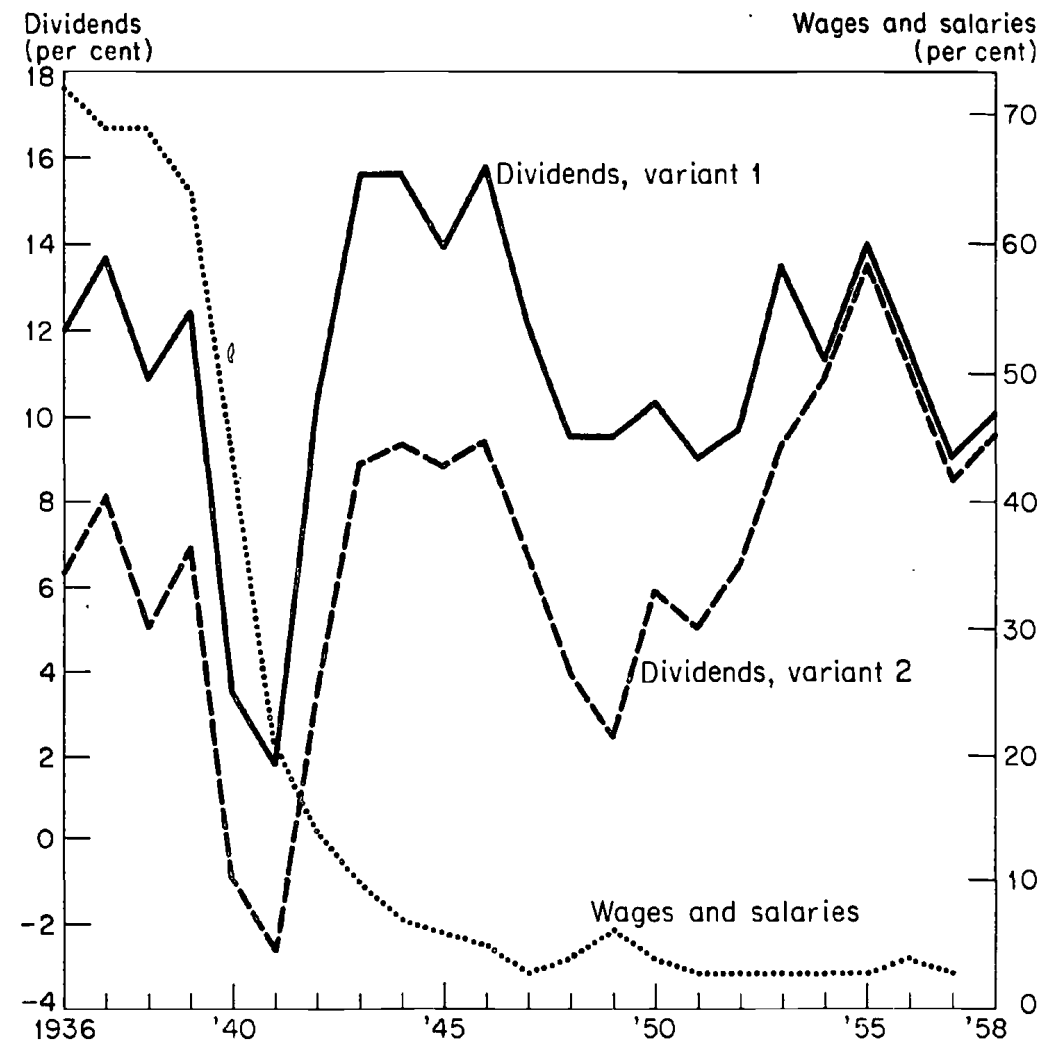

1956, the dividends of all fiduciaries, i.e., both taxable and nontaxable, were tabulated and published. Special features of the 1954 data make it inappropriate for the purpose at hand, ${ }^{21}$ so it is excluded in what follows. For these five years, then, the variant 2 values are less

21 Adjustments would be needed because the dividend exclusion and credit were in effect for only part of the year. 


\section{Dividend Underreporting on Tax Returns}

open to question since the dividends of nontaxable fiduciaries did not have to be estimated.

The early set of years (1937-1939) may be compared with the more recent ones (1952 and 1956) first in terms of the scope and coverage of the income tax, using 1939 specifically to represent the earlier years and 1952 the more recent period. In 1939, filing requirements were $\$ 2,500$ or $\$ 1,000$ of net income for married or single taxpayers respectively, or $\$ 5,000$ of gross income regardless of net; less than 2 million dividend returns and less than 8 million returns in all (both individual and fiduciary) were filed; and about 40 per cent of total adjusted gross income was reported on tax returns. In 1952, filing requirements were $\$ 600$ of adjusted gross income (whether married or single); well over 4 million dividend returns and just under 57 million returns in all were filed; and about 92 per cent of total adjusted gross income appeared on tax returns. ${ }^{22}$ Then 1937-1939 should be com. pared with 1952 and 1956 in terms of the coverage of dividends on tax returns. For earlier years, the gap is between $\$ 150$ and $\$ 350$ million, or between 5 and 8 per cent of total dividends; for the more recent two years, the gap is about $\$ 523$ million in 1952 , about 6.5 per cent of total dividends, and $\$ 1.2$ billion, or 10 per cent of total dividends, in 1956.

Here and in the rest of this chapter, as a general rule, we discuss the gap as a single number instead of a range because the ranges are clearly different, i.e., they do not overlap. For example, the average gap for 1937-1939 is significantly different from that in 1952 and 1956, by the test explained in the note appended to this chapter.

From what is known about the extension of the scope and coverage of the tax system between the earlier and later periods, one would expect, other things unchanged, that the gap should have become less pronounced. But a gap in absolute magnitude several times as large as the earlier one and in relative terms substantially the same if not larger strongly suggests that, in fact, something did change. It is hard to resist concluding that in these two later years dividend recipients were not reporting their dividends as fully as in earlier years. ${ }^{23} \mathrm{~A}$

22 Filing requirements and number of returns are from Statistics of Income for 1939, Part 1, pp. 122 and 298; Statistics of Income for 1952, Part 1, pp. 18, 70, and 89 . Adjusted gross income percentages are estimated by C. Harry Kahn.

${ }^{23}$ There is no intention here of claiming specifically that those who reported in 1937-1939 and in 1952 and 1956 reported less fully in the later period. The statement applies simply to dividend recipients in general at these two sets of dates. 


\section{Dividends Under the Income Tax}

TABLE 18

Effective Rates of Individual Income Tax for a Married Person with Two Dependents and a Single Person, at Selected Levels of Net Income, 1940-1954

\begin{tabular}{|c|c|c|c|c|c|c|c|c|c|c|c|c|}
\hline $\begin{array}{c}\text { Net } \\
\text { Income } \\
\text { Level } \\
\text { (dollars) }\end{array}$ & $\begin{array}{l}1936- \\
1939\end{array}$ & 1940 & 1941 & 1942 & 1943 & $\begin{array}{l}1944 \\
\text { and } \\
1945\end{array}$ & $\begin{array}{r}1946 \\
\text { and } \\
1947\end{array}$ & $\begin{array}{l}1948 \\
\text { and } \\
1949\end{array}$ & 1950 & 1951 & $\begin{array}{l}1952 \\
\text { and } \\
1953\end{array}$ & $\begin{array}{l}1954- \\
1960\end{array}$ \\
\hline \multicolumn{13}{|c|}{ MARRIED, TWO DEPENDENTS } \\
\hline 3,000 & - & - & 1.9 & 6.4 & 8.9 & 9.2 & 6.3 & 3.3 & 3.5 & 4.1 & 4.4 & 4.0 \\
\hline 5,000 & 1.0 & 1.5 & 5.4 & 11.8 & 14.6 & 15.1 & 11.8 & 8.6 & 9.0 & 10.6 & 11.5 & 10.4 \\
\hline 10,000 & 3.4 & 4.4 & 11.2 & 19.1 & 22.1 & 22.5 & 18.6 & 13.6 & 14.2 & 16.2 & 17.7 & 15.9 \\
\hline 50,000 & 17.2 & 27.5 & 39.9 & 49.7 & 52.8 & 53.7 & 48.2 & 33.2 & 34.3 & 38.5 & 42.2 & 37.8 \\
\hline 100,000 & 32.0 & 42.9 & 52.2 & 63.5 & 67.8 & 68.6 & 62.3 & 45.6 & 47.2 & 52.6 & 56.0 & 51.9 \\
\hline 500,000 & 60.7 & 65.9 & 68.9 & 82.7 & 88.0 & 88.6 & 81.3 & 71.7 & 73.9 & 80.7 & 82.2 & 80.5 \\
\hline \multicolumn{13}{|c|}{ SINGLE PERSON, NO DEPENDENTS } \\
\hline 3,000 & 2.3 & 2.8 & 7.4 & 15.7 & 19.1 & 19.5 & 16.2 & 13.6 & 14.3 & 16.6 & 18.1 & 16.3 \\
\hline 5,000 & 2.8 & 3.4 & 9.7 & 18.4 & 22.1 & 22.1 & 18.4 & 16.2 & 16.9 & 19.3 & 21.0 & 18.9 \\
\hline 10,000 & 5.6 & 6.9 & 14.9 & 23.9 & 27.8 & 27.6 & 23.5 & 21.2 & 22.0 & 24.9 & 27.2 & 24.4 \\
\hline 50,000 & 18.7 & 29.4 & 41.8 & 51.6 & 56.1 & 55.9 & 50.3 & 46.4 & 48.0 & 53.5 & 56.9 & 52.8 \\
\hline 100,000 & 33.0 & 44.3 & 53.2 & 64.6 & 69.7 & 69.9 & 63.5 & 58.0 & 60.8 & 67.3 & 69.7 & 66.8 \\
\hline 500,000 & 61.0 & 66.2 & 69.1 & 82.9 & 88.4 & 88.9 & 81.6 & 77.0 & 79.2 & 86.0 & 87.2 & 85.9 \\
\hline
\end{tabular}

SoURce: The Federal Revenue System: Facts and Problems, Materials Assembled for the Subcommittee on Tax Policy, Joint Committee on the Economic Report, 1959, p. 192.

ready explanation for the decline in reporting zeal lies in tax rates, which of course were much higher in 1952 and 1956 than in 1937-1939. Changes in tax rates over this period are summarized in Table 18. At the lower income levels, effective rates rose by multiples of 5 to 10 . For the higher income levels the severity of the rise may be more appropriately judged by the percentage decrease in income after tax as shown in Table 19.

Persons in doubt as to whether to report dividends or not might be more directly influenced by marginal rates. But these in general tell much the same story. For example, a married man with two dependents failing to report a dollar of dividend receipts at the $\$ 5,000$ net income level would have saved 4 cents in 1939, but over 22 cents in 1952; at $\$ 10,000$, the tax saving would have been 9 and 25 cents, respectively; at $\$ 50,000$, it would have been 31 and 66 cents; while at $\$ 500,000$ it would have been 62 and 92 cents. Even more pronounced at most income levels are the differences between 1939 and 1952 rates for separate returns.

Parenthetically it may be observed from Chart 3 that the coverage percentage for wages and salaries behaved in a fashion consistent with (1) the pronounced decline in exemptions starting with the war, (2) 


\section{Dividend Underreporting on Tax Returns}

TABLE 19

Percentage Increase in Effective Rates and Percentage Decline in Income After Tax, at Selected Net Income Levels, Between 1939 and 1952

\begin{tabular}{ccc}
\hline \hline $\begin{array}{c}\text { Net } \\
\text { Income Level } \\
\text { (dollars) }\end{array}$ & $\begin{array}{c}\text { Percentage } \\
\text { Increase in } \\
\text { Effective Rates }\end{array}$ & $\begin{array}{c}\text { Percentage } \\
\text { Decrease in } \\
\text { Income After Tax }\end{array}$ \\
\multicolumn{3}{c}{ MARRIED, Two DEPENDENTs } \\
3,000 & a & 4 \\
5,000 & 1,050 & 11 \\
10,000 & 421 & 15 \\
50,000 & 145 & 30 \\
100,000 & 75 & 35 \\
500,000 & 35 & 55 \\
& \\
3,000 & sinaLe, No DEPENDENTs & 16 \\
5,000 & 687 & 19 \\
10,000 & 650 & 23 \\
50,000 & 386 & 47 \\
100,000 & 204 & 55 \\
500,000 & 111 & 67 \\
\hline
\end{tabular}

a No tax in 1939.

the general increase in income from 1936 on, and (3) the institution of withholding of almost all of the wages and salary tax liability in 1943.

In my judgment, this evidence on the change in the dividend "gap" between 1937-1939 and 1952 and 1956 suggests that one response to high tax rates has been an increase in the amount of dividends stockholders fail to report. ${ }^{24}$ Yet stockholders should not be singled out on

24 One rational response to increased tax rates would be the splitting up of stock ownership and dividend income within the family unit to minimize tax liability. This could be done by giving stock to minors or to a spouse. The tax advantage of arrangements that change stock ownership from husband to wife or vice versa was substantially removed by the introduction of income splitting in 1948. It is not likely that to get a relatively small amount of dividends down to a nontaxable level, the advantages of income splitting would be foregone. What happened between 1947 and 1948 suggests that, prior to general income splitting where there was a parceling out of stock ownership within the family, the primary effect was to get dividends down lower in the tax schedule, but not down so low that they did not have to be reported. For while the number of taxable returns reporting dividends (see Chapter I) fell between these years by about 300,000 , the increase of $\$ 760 \mathrm{mil}$ lion between 1947 and 1948 in dividends reported as such on tax returns in relation 
this score. We concentrate on them because this study happens to be concerned with dividends. But, there are good reasons to think that underreporting also increased (or reporting failed to increase as much as it should have) for some other sources of income. ${ }^{25}$

\section{POSITIVE ASSOCIATION BETWEEN UNDERREPORTING AND LEVEL OF TAX RATES}

It seems possible to go beyond the comparison based on two sets of widely separated years and discover a more general association between variations in tax rates and the size and relative importance of the dividend gap, but with qualifications and exceptions. If, as already noted, a decline in exemptions or filing requirements is not accompanied by a constant or falling gap as we measure it, or if a rise in exemptions or filing requirements is not accompanied by a constant or rising gap, ${ }^{26}$ then other factors must explain variations in the gap. Variation in tax rates is one such factor. Another possible explanatory variable to be discussed later is the relative change in aggregate dividend payments.

The basis for judging that the change in tax rates has had an effect lies in a review of the change in the gap from 1936 to 1958. It makes little difference for this purpose whether we use variant 1 or 2, although the timing of effects will, on occasion, show up differently under each variant. For convenience again, a single value will be used rather than the conceptually more appropriate confidence interval. But we will only draw conclusions about changes in the gap

to the $\$ 650$ million increase in total personal dividends is very much the same as the $\$ 750$ million increase in dividends reported as such on tax returns between 1946 and 1947 in relation to the $\$ 660$ million change in total personal dividend payments between these two years. Therefore we can infer that transfer of stock ownership (and, hence, dividends) between married partners may have put some dividends into lower tax brackets, but freed only a relatively small amount of dividends from the necessity of having to be reported. As regards gifts to minors, over the span of years under discussion here this had to be effected via a trust arrangement. To the extent that such trusts had enough income to be required to file, their dividend receipts are included in our estimates via dividends of fiduciaries. Recent legislation, starting in 1954, has simplified this procedure, and currently in all fifty states transfer of stock to minors is permitted without the necessity of setting up a trust. Another possibility, giving stocks to charities and foundations, if availed of, would show up in our estimates in the dividend receipts of nonprofit organizations.

${ }^{25}$ See, for example, the two articles by Selma Goldsmith cited earlier; Holland's "Unreporting of Dividends and Interest on Tax Returns" and C. Harry Kahn's "Coverage of Entrepreneurial Income on Tax Returns," both in Tax Revision Compendium, Vol. 2, pp. 1439-1459.

26 The expectation of a constant gap is a possibility under both these conditions because of the high concentration of the dividend distribution. 


\section{Dividend Underreporting on Tax Returns}

that stand up under the significance test described in the note at the end of this chapter. Thus, we shall speak about a "sharp" fall in the gap between two years only when a difference of this magnitude could not be due to random variability in the data more than one time in a hundred. We stress once more that it is only the distortions of random errors of measurement that we eliminate in our significance test. The biases could still affect the results, although it is our judgment that they are not strong enough to determine the results. But there is no way to prove this.

The initially high coverage of dividends on tax returns and the tendency for the gap to decline from 1936 through 1941 follow from the relatively small number of persons who received relatively large amounts of dividends, and the sharp decline in exemptions and filing requirements in 1940 and 1941. This latter can be summarized simply by noting that in 1939 about 40 per cent of total adjusted gross income could be traced to tax returns, and by 1942 the percentage was $81 .{ }^{27}$ As evidence of the increased scope of the income tax, we find the percentage of dividends not traceable to tax returns declining, under variant 1 , by over 70 per cent between 1939 and 1940 and to slightly below zero, according to variant 2 . And we find the relative gap further below zero by 1941 if we follow variant 2 ; under variant 1 , it is cut in half between 1940 and 1941. In absolute terms, too, of course, dividends not reported on tax returns underwent a pronounced decline, under both variants. The negative gap in variant 2 for 1940 and 1941 is not as remarkable as it may seem. It should be recalled that we take as accounted for the dividends reported by fiduciaries whether distributed or retained. Since we also estimate the dividend component of the fiduciary income of individuals, some double counting that leads to an overstatement of coverage (an understatement of the gap) is involved here. In view of the general lack of precision of our estimates, the negative gap should be taken to indicate no more than that dividend receipts not traceable to tax returns came to a very small total. In a sense, the 1941 results constitute a rock bottom figure for the gap, the coverage of dividends on tax returns being so high that one would not expect a decrease in the gap despite the further lowering of filing requirements and the upward movement of incomes, both of which led to a higher fraction of the population and its income receipts coming under the personal income tax. Nor would it be sur-

27 In 1939, less than 8 million returns were filed; in 1942 the number of returns cxceeded 36 million. 


\section{Dividends Under the Income Tax}

prising, given the roughness of our estimates, if the gap increased slightly under these conditions.

But it did not remain substantially unchanged. On the contrary, the amount and relative degree of noncoverage on tax returns increased substantially in 1942 and again in 1943. Compared with the dividend gap under variant 2 of minus $\$ 107$ million in 1941, there was a gap of $\$ 141$ million in 1942 , and $\$ 363$ million in 1943. (In variant 1 a similar rise occurred, from $\$ 74$ million in 1941 to $\$ 412$ million in 1942 and $\$ 638$ million in 1943.) And all these changes in the gap are statistically significant. In relative terms, variant 2 shows in sharp contrast to a gap of below zero in 1941, a nonreported percentage of over 3.5 in 1942 and close to 9 in 1943; variant 1 gives a rise from under 2 to over 15 per cent. This does not square with the following evidence: Between 1941 and 1942, the number of returns filed increased by 11 million; between 1942 and 1943 there was an additional increase of 7 million. (All the data for 1942 and 1943 are as tabulated in Statistics of Income, rather than adjusted for withholding. But this does not affect their relevance for our purpose.)

Some of this rise in dividends not reported can be explained by the special tax provisions for military personnel, but in any reasonable estimate this could account for only a small part of the increase. ${ }^{28}$ Nor

28 Those serving abroad were permitted, beginning in 1941 and ending June 15, 1948 , to defer filing until six months after their return to the United States (Statistics of Income, pt. I, 1948, p. 428). In 1942 an exclusion of $\$ 250$ if single and $\$ 300$ if married was permitted noncommissioned personnel. In 1943 this was raised to an exclusion of the first $\$ 1,500$ of military pay for all members of the Armed Forces. But it is doubtful whether these provisions could explain much of the decline in dividend reporting. The following gives a rough idea of the relevant order of magnitude. In late 1951 or early 1952 when there were 1.8 million persons in the Armed Forces, it has been estimated that members of the Armed Forces who were "menbers of family groups" constituted 0.3 per cent of the total number of individual share-owners (Lewis H. Kimmel, Share Ownership in the United States, Brookings Institution, Washington, 1952, p. 98). This can be raised to 0.4 per cent to take account of those not members of family groups, and it can be assumed to apply to dividend receipts from both publicly (large and widely owned) and privately owned corporations as well as to stock ownership. We assume further that this same percentage held in 1941 when the average number in the Armed Forces was roughly comparable, and, finally, that new accretions to the military during 1942 and 1943 received 50 per cent more dividends than those in the Armed Forces in 1941, and that none of these additions filed tax returns. (All of these assumptions work toward overstating the dividends legitimately not reported by members of the Armed Forces. This last one, for example, implies they were all serving abroad.)

Then we can attribute about 1 point of the 6.2-point rise of variant 2 in the nonreported percentage between 1941 and 1942 to dividends of members of the 


\section{Dividend Underreporting on Tax Returns}

is it realistic to expect that much of this increase in the gap can be explained by a sudden sharp increase in intrafamily shuffling of stock ownership to minimize tax liability. ${ }^{20}$ Between 1941 and 1943 the rate increases were severe and concentrated, of course, in a short span of years. ${ }^{30}$ Apparently more taxpayers were pushed below the margin of honesty as it became more profitable not to report dividend receipts (as well as other sources of income). But this should not be viewed as a purely mechanical response. In part it may be due to the shock effect of the rapidity of the rate rise. The increase in the gap over this period may also, in part at least, simply be one expression of the lower standard of conduct that characterized other areas as well during the war years. ${ }^{31}$

Armed Forces and between 1.5 and 2 points of the 5.3-point rise of variant 2 between 1942 and 1943 to this same factor. Thus, correcting for the Armed Forces, the 1942 percentage for dividends not reported would read 2.6 and the 1943 one between 7 and 7.5 (both as measured by variant 2). These are still very different from 1941. And our adjustment for dividends received by those in the Armed Forces is undoubtedly excessive.

20 To the extent that this took the form of trust arrangements, the dividends are in the main included in our figures. Other ways of arranging stockholdings probably were availed of earlier, since tax rates were by no means negligible before 1942 . Moreover, much of the reshuffling to minimize taxes involved not taking dividend receipts out of the tax return population, but pushing them lower down the marginal rate schedule. That such had been the case is suggested by a comparison of the data immediately before and just after the introduction of income splitting for married persons in 1948, as noted in an earlier footnote.

$30 \mathrm{~T}$ wo factors are involved in the problem under discussion here. With everything else unchanged, an extension of the coverage of the tax system would tend to close the "gap," but an increase in rates would tend to open it by increasing the tax saving associated with underreporting. Thus, apparently, the increased scope of the tax system brought in more dividends between 1940 and 1941 than the rise in rates between these two years squeezed out. But by 1941 most of the tax base expansion had taken place, yet in the years that followed rates were raised further.

31 In reviewing an earlier draft of this manuscript, W. Leonard Crum pointed out an alternative to my explanation of this increase in the gap as a response to higher tax rates:

"Another 'ready explanation' is that the increased reach of the tax system brought in many new taxpayers, many of whom did not think they needed to 'bother' with reporting dividends, most of whom had not become over the years habituated to keep records and report income from a variety of sources, and some of whom regarded the new taxes thrust upon them as an undeserved burden which justified any sort of evasion which was likely to escape discovery (and such evasion was likely to escape discovery in a period when the Bureau was swamped with the huge increase in number of returns without a corresponding increase in the trained per. sonnel for the enforcement of the act)."

(With the exception of this quotation and the question raised by Willard Thorp mentioned earlier, numerous suggestions from persons who read this study in draft 


\section{Dividends Under the Income Tax}

Yet, after the war was over, dividend reporting did not revert to its prewar level. In 1940, for example, with the income tax covering less than three-fifths of the income received by persons, almost all dividends showed up on tax returns; while in 1946, less than 91 per cent could be so traced by variant 2 (about 84 per cent under variant 1), although 90 per cent of all income was covered by the tax structure. In 1936, when the income tax was still a select levy, the gap constituted 6.3 per cent of total dividends as measured by variant 2 , or 12 per cent under variant 1 , although only little more than a third of the community's income was called to account for tax purposes. This contrasts with the experience ten years later-a gap of 9.4 per cent or 15.8 per cent for variants 2 and 1 , respectively.

Effective tax rates at given income levels reached a peak in 19441945. Over the next four years, increases in exemptions, the lowering of rate schedules, and, most significantly for married persons, the extension of income splitting to all joint returns (in 1948), all led to a decline in effective rates. This decline was substantial; for married couples, at least, at most income levels, by 1948 legislated effective rates were somewhere between their 1941 and 1942 values; for separate returns the decline was not as pronounced. (Of course, to the extent that their incomes increased, taxpayers were subject to higher effective rates than a comparison of legislated rates at a given income level would indicate.) Along with this decline in effective rates we find that the dividend gap fell in absolute amount under both variants. With the aggregate flow of dividend payments increasing over time, there was a more pronounced decline in the relative importance of the gap. Between 1946 and 1949, the relative gap fell by more than 60 per cent under variant 2; from 15.8 to 9.5 per cent as measured by variant $1 .{ }^{32}$

Thus it appears, especially if we focus on the relative size of the gap, that the response to tax rates has been symmetrical-just as underreporting increased when rates rose, so it declined when tax rates fell. But the fall in underreporting was not as vigorous as its earlier rise. The gap remained relatively much larger than in 1940 or 1941 .

Is this finding borne out from 1950 on? A glance at Table 18 shows

form have been adopted without specifically noting the suggestion or the person who made it.)

32 The decline over this period is all the more noteworthy because the increase in exemptions and filing requirements from $\$ 500$ of adjusted gross income to $\$ 600$ in 1948 should, as we measure it, have led, other things equal, to a rise in the gap. 


\section{Dividend Underreporting on Tax Returns}

a slight rise in tax rates between 1949 and 1950, more severe increases in 1951,1952 , and 1953, and then a fairly pronounced fall in 1954, with a continuance of rates at the 1954 level up through the present. In general, the behavior of the dividend gap over this period does not strongly confirm our conclusion that there is a relation between the dividend gap and changes in tax rates. The relation is weak, and there was a lagged response. Thus it was not until 1953 that the variant 1 gap (on a relative basis) had become noticeably higher than in 1949; the evidence of variant 2 , however, shows a more immediate response to tax rate increases.

The behavior of the gap between 1953 and 1955 does not support our generalization. Here reliance is placed on variant 1 because, with the change in tax treatment of dividends introduced in 1954 (the exclusion of $\$ 50$ for separate returns and $\$ 100$ for joint returns, and the credit against tax of 4 per cent of dividends above the excluded amount) the variant 2 values for 1954 are adjusted estimates and quite liable to be out of line with the run of years up to that time. If we examine the variant 1 gap, as measured in relative terms, we find it falling between 1953 and 1954, which is consistent with the sharp decline in tax rates. Surprising, however, is the rise in the gap between 1954 and 1955 (found also for variant 2) in the face of tax rates that did not vary between these two years. Moreover, in the face of constant tax rates there is a substantial decline between 1955 and 1957. Quirks in our data could, of course, be a possible explanation of the behavior of the gap over these years; so, too, could be some special feature of the data since 1954 that our method has not adequately adjusted for. Or it might be that taxpayers were reporting more thoroughly. But there is another possibility suggested by these results.

As an alternative to our hypothesis that changes in the gap are related to change in tax rates, or merely as another factor affecting the size of the gap, it could be that the dividend gap is positively associated with sharp increases in the total volume of dividends paid out, either because new people, unaccustomed to reporting (or even record-keeping) were receiving them, or because, with a large increase in dividend payments, the recipients thereof would have a higher tax liability and, particularly if pushed into a higher bracket, their incentive to underreport would be stronger.

But this simple conjecture is difficult to test, for to do so we would have to be able to remove the effects on the gap exercised by (1) the 


\section{Dividends Under the Income Tax}

extension of the income tax to more income recipients and (2) changes in tax rates. We are able, however, to cite data that show a positive association between pronounced changes in dividend payments and percentage changes in the size of the relative dividend gap. From our data we have picked out the periods of "sharpest" year-to-year change in total dividend payments (our estimates of dividends adjusted for comparability with tax returns) and the change in the relative dividend gap, measuring both sets of changes as percentages. The results are summarized in Table 20, the first row of which shows, for example, that between 1938 and 1939 aggregate dividends increased by 18 per cent, the relative dividend gap went up some 35 per cent under variant 1 and 63 per cent under variant 2.

On first glance, the evidence does not seem to support the hypothesis that sharp increases in total dividends and increases in the dividend gap are associated. Under variant 1, in four of the eight periods of dividend increase the gap fell; for variant 2 this happened in three instances. But a closer look provides limited support for the hypothesis. The four periods of largest relative increase in aggregate dividends-

TABLE 20

Comparison of Percentage Changes in Aggregate Personal and fiduciary Dividends a and in Dividend Gap for Selected Two-Year Periods

(per cent)

\begin{tabular}{cccc}
\hline \hline & $\begin{array}{c}\text { Aggregate } \\
\text { Dividends } \\
(1)\end{array}$ & $\begin{array}{c}\text { Relative Dividend Gap } \\
\text { Variant 1 } \\
(3)\end{array}$ & $\begin{array}{c}\text { Variant 2 } \\
(4)\end{array}$ \\
\hline $1938-1939$ & 18 & 35 & 63 \\
$1940-1941$ & 10 & -43 & $215^{\circ}$ \\
$1945-1946$ & 23 & 40 & 32 \\
$1946-1947$ & 12 & -14 & -20 \\
$1947-1948$ & 11 & -13 & -35 \\
$1949-1950$ & 23 & 34 & 196 \\
$1954-1955$ & 14 & 41 & 42 \\
$1955-1956$ & 6 & -7 & -46 \\
\hline
\end{tabular}

a Adjusted for comparability with tax return data; see line 14 of Table 23 in note at end of this chapter.

b A minus sign in cols. 3 and 4 indicates that a decrease in the relative dividend gap was associated with an increase in aggregate dividend payments.

- The positive percentage in this case came from a negative numerator and denominator. 


\section{Dividend Underreporting on Tax Returns}

1938-1939, 1945-1946, 1949-1950, and 1954-1955-all showed a positive increase in the relative dividend gap.

In closing this portion of our discussion of the dividend gap, it is appropriate to repeat the need for caution in interpreting the results. Only those findings that seem to stand out despite the imprecision of our data and estimates have been set forth. Yet they remain more in the nature of personal judgments than established facts. That there are errors of estimate in our measure of the dividend gap cannot be denied. The random errors we have taken into account. That there are likely to be biases affecting the size of the gap cannot be denied either. Yet, there are good grounds for holding that the distortion would not be large enough to affect our conclusions on the behavior of the gap. Of the adjustments made in arriving at the estimates of the dividend gap (with the exception of fiduciary dividends which have already been discussed and for which alternative estimates have been made), the most sizable is dividend receipts of nonprofit organizations (see line 9 of Table 26 in the note at the end of this chapter). For the other estimated entries, "big" percentage errors would have only a slight effect on the gap. And our estimate of the dividend receipts of nonprofit organizations appears to be well above two others that have been made. ${ }^{33}$ Thus on this score our estimates make for a smaller gap than would either of the two alternative figures just cited.

\section{Income Class Distribution of Dividend Underreporting}

Granted that taxpayers fail to report a slice of their dividend receipts and that the size and relative importance of this slice has apparently responded to variations in tax rates, it is also of interest to know, for example, where the underreporting is concentrated and how much of it might be uncovered by audit. An attempt to answer such questions is possible from the evidence uncovered for 1948 by the Internal Revenue Service (then the Bureau of Internal Revenue), and very recently for 1959 .

33 For 1952 we obtained a figure of $\$ 338$ million. Selma Goldsmith puts it at $\$ 200$ million for that year (see Selma F. Goldsmith, "The Relation of Census Income Distribution Statistics to Other Income Data," in An Appraisal of the 1950 Census Income Data, Studies in Income and Wealth 23; and the Federal Reserve Board's flow of funds estimate is $\$ 100$ million for 1952 (data from Federal Reserve Board worksheets). 


\section{Dividends Under the Income Tax}

THE 1948 DATA

The Bureau undertook a careful statistical investigation of the tax returns filed in 1948-the audit control program (hereinafter referred to as the ACP)-designed to "determine the size of the individual tax enforcement problem confronting the Bureau of Internal Revenue." 34 For a scientific sample of tax returns, errors (e.g., reporting less or more than should have been reported) and the amount of tax change associated with them were determined by audit, and from this information estimates for the whole taxpaying population were made. ${ }^{35}$ These data on errors, including those made in reporting dividends, and the resulting tax change were tabulated in four broad income classes: under $\$ 7,000, \$ 7,000$ to $\$ 25,000, \$ 25,000$ to $\$ 100,000$, and $\$ 100$,000 and over. This makes it possible to analyze the income class distribution of underreporting as determined by dividing tax changes disclosed by audit by the appropriate marginal rates. Since a number of assumptions were necessary in obtaining these estimates, it is more appropriate to present them as ranges rather than to use a single figure that might spuriously suggest more precision than was possible. ${ }^{30}$

Table 21 shows our estimates for dividends uncovered by the ACP. In the aggregate we estimate that between $\$ 90$ and $\$ 179$ million of dividends would have been uncovered in 1948 had all returns been carefully audited, which comes to between 1.8 and 3.6 per cent of the amount of dividends actually reported by individuals. About one-third of dividend underreporting was found in the lowest income class, about half in the class $\$ 7,000$ to $\$ 25,000$, and the rest in the income groups of $\$ 25,000$ and over. More significant, however, is the relative degree of underreporting among income classes. Reading from low to high income classes, a general tendency appears for the amount and relative importance of underreporting to vary inversely with income class. Dividends discovered by the ACP ${ }^{37}$ fell in a range of something like 3 to 6 per cent of those voluntarily reported for the two lower income classes, and between 1 and 2 per cent for the $\$ 25,000$-to- $\$ 100,000$

34 Bureau of Internal Revenue, The Audit Control Program, A Summary of Preliminary Results, p. 3. A generally similar survey was made for 1949 , but no data relevant to our problem are currently available.

s5 The auditors and auditing procedures of the ACP were probably superior to those generally in use at that time.

36 Details of the estimating procedures appear in the note to this chapter. The estimates are based on materials made available by the Internal Revenue Service in 1951 .

37 This, of course, is our estimate from the tax change data released by the ACP. 


\section{Dividend Underreporting on Tax Returns}

TABLE 21

Estimates of Amount of Dividend Underreporting and Frequency of Such Errors in 1948 Derived from Audit Control Program Data

\begin{tabular}{|c|c|c|c|c|c|c|c|}
\hline $\begin{array}{c}\text { Income Class } \\
\text { (1) }\end{array}$ & $\begin{array}{l}\text { Estimated } \\
\text { Dividend } \\
\text { Under- } \\
\text { reporting } \\
\text { (million } \\
\text { (2) }\end{array}$ & $\begin{array}{l}\text { Dividends } \\
\text { Reported } \\
\text { llars) } \\
\quad \text { (3) }\end{array}$ & $\begin{array}{c}\text { Col. } 2 \\
\text { as } \\
\text { Per Cent } \\
\text { of } \\
\text { Col. } 3 \\
\text { (4) }\end{array}$ & $\begin{array}{l}\text { Estimated } \\
\text { Number of } \\
\text { Under- } \\
\text { reporting } \\
\text { Errors }{ }^{\mathrm{a}} \\
\text { (thou- } \\
\text { sands) } \\
\text { (5) }\end{array}$ & $\begin{array}{l}\text { Number of } \\
\text { Returns } \\
\text { Reporting } \\
\text { Dividends } \\
\text { (thou- } \\
\text { sands) } \\
\text { (6) }\end{array}$ & $\begin{array}{c}\text { Col. } 5 \\
\text { as } \\
\text { Per Cent } \\
\text { of } \\
\text { Col. } 6 \\
\text { (7) }\end{array}$ & $\begin{array}{c}\text { Per Cent } \\
\text { of Total } \\
\text { Estimated } \\
\text { Dividend } \\
\text { Under- } \\
\text { reporting } \\
(8)\end{array}$ \\
\hline $\begin{array}{l}\text { Under } \$ 7,000 \\
\$ 7,000 \text { to } \$ 25,000^{b} \\
\$ 25,000 \text { to } \$ 100,000 \\
\$ 100,000 \text { and over }\end{array}$ & $\begin{array}{c}30.9-61.7 \\
42.2-84.3 \\
14.0-28.0 \\
2.6-5.1\end{array}$ & $\begin{array}{l}1,110.3 \\
1,351.2 \\
1,508.4 \\
1,001.0\end{array}$ & $\begin{array}{l}2.8-5.6 \\
3.1-6.2 \\
0.9-1.9 \\
0.3-0.5\end{array}$ & $\begin{array}{r}297.5 \\
159.5 \\
31.2 \\
2.5\end{array}$ & $\begin{array}{r}2,345.6 \\
794.9 \\
166.9 \\
14.5\end{array}$ & $\begin{array}{l}12.7 \\
20.1 \\
18.7 \\
17.2\end{array}$ & $\begin{array}{r}34.5 \\
47.1 \\
15.6 \\
2.9\end{array}$ \\
\hline Total & $89.6-179.1$ & $4,970.9$ & $1.8-3.6$ & 490.7 & $3,321.9$ & 14.8 & 100.0 \\
\hline
\end{tabular}

a Includes both returns on which dividends were reported, but too low, and those that should have reported dividends, but did not. These latter, which should have been added to column 5, are not included there, because there is no way of estimating them.

$b$ The estimate for this class also covers errors on business returns with adjusted gross income of less than $\$ 7,000$ where gross receipts exceeded $\$ 25,000$.

class, and between 0.25 and 0.5 per cent for the top income class. These results seem reasonable. In the upper income classes record-keeping is superior as a rule, the consequences of not reporting more serious, and audit is a more likely possibility. This ties in with some of our previous remarks and also with Crum's comment quoted in an earlier footnote.

The frequency of errors in dividend reporting was more prominent than the rather slight amount of unreported dividends as estimated from the ACP data. The estimated 490,700 returns with dividend underreporting errors represented close to 15 per cent of the total number of returns reporting dividends. For all but the lowest income class, however, the percentage was above this, ranging between 17 and 20 and varying but slightly with income class (see column 7 of Table 21). Thus the practice of underreporting was less prevalent (relatively) in terms of numbers in the lowest income class than any other, but otherwise about the same for the remainder of the income range. Together with the finding noted earlier on the relative importance of the amount underreported-the ratio of underreported to reported dividends tended to decline with income class-this suggests that individually underreporting errors were considerably more important in the 


\section{Dividends Under the Income Tax}

TABLE 22

Estimated Absolute and Relative Size of Underreporting and Overreporting Errors for Returns with Major and Minor Errors in Dividends, 1948

\begin{tabular}{|c|c|c|c|c|c|c|c|}
\hline \multirow[b]{2}{*}{$\begin{array}{c}\text { Income Class } \\
\text { (1) }\end{array}$} & \multirow[b]{2}{*}{$\begin{array}{c}\text { Average } \\
\text { Amount of } \\
\text { Dividends } \\
\text { Reported } \\
\text { (dollars) } \\
\text { (2) }\end{array}$} & \multicolumn{3}{|c|}{ Returns with Major Errors in Dividends } & \multicolumn{3}{|c|}{ Returns with Minor Errors in Dividends } \\
\hline & & $\begin{array}{l}\text { Number } \\
\text { of } \\
\text { Returns } \\
\text { (thous.) } \\
\text { (3) }\end{array}$ & $\begin{array}{c}\text { Estimated } \\
\text { Average } \\
\text { Error } \\
\text { (dollars) } \\
\text { (4) }\end{array}$ & $\begin{array}{c}\text { Errors as } \\
\text { Per Cent } \\
\text { of Amount } \\
\text { Reported } \\
\text { Col. } 4+\text { Col. } 2 \\
\text { (5) }\end{array}$ & $\begin{array}{c}\text { Number } \\
\text { of } \\
\text { Returns } \\
\text { (thous.) } \\
\text { (6) }\end{array}$ & $\begin{array}{l}\text { Estimated } \\
\text { Average } \\
\text { Error } \\
\text { (dollars) } \\
(7)\end{array}$ & $\begin{array}{c}\text { Errors as } \\
\text { Per Cent } \\
\text { of Amount } \\
\text { Reported } \\
\text { Col. } 7 \underset{\dot{1}}{ } \text { Col. } 2 \\
\text { (8) }\end{array}$ \\
\hline \multicolumn{8}{|c|}{ UNDERREPORTING ERRORS } \\
\hline $\begin{array}{l}\text { Under } \$ 7,000 \mathrm{a} \\
\$ 7,000 \text { to } \$ 25,000^{b} \\
\$ 25,000 \text { to } \$ 100,000 \\
\$ 100,000 \text { and over }\end{array}$ & $\begin{array}{r}265 \\
978 \\
7,939 \\
66,732\end{array}$ & $\begin{array}{r}129.2 \\
65.5 \\
12.2 \\
1.0\end{array}$ & $\begin{array}{c}110-220 \\
237-473 \\
426-852 \\
1,000-2,000\end{array}$ & $\begin{array}{c}41.5-90.0 \\
24.2-48.4 \\
5.4-10.8 \\
1.5-3.0\end{array}$ & $\begin{array}{r}128.5 \\
94.0 \\
19.0 \\
1.5\end{array}$ & $\begin{array}{c}126-251 \\
312-624 \\
542-1,084 \\
1,334-2,667\end{array}$ & $\begin{array}{c}47.5-95.0 \\
31.9-63.8 \\
6.8-13.6 \\
2.0-4.0\end{array}$ \\
\hline \multicolumn{8}{|c|}{ OVERREPORTING ERRORS } \\
\hline $\begin{array}{l}\text { Under } \$ 7,000^{\mathrm{a}} \\
\$ 7,000 \text { to } \$ 25,000 \\
\$ 25,000 \text { to } \$ 100,000 \\
\$ 100,000 \text { and over }\end{array}$ & $\begin{array}{r}265 \\
978 \\
7,939 \\
66,732\end{array}$ & $\begin{array}{l}7.6 \\
8.1 \\
1.8 \\
0.2\end{array}$ & $\begin{array}{l}39-78 \\
155-310 \\
231-461 \\
700-1,400\end{array}$ & $\begin{array}{c}14.7-29.8 \\
15.8-31.6 \\
2.9-5.8 \\
1.0-2.0\end{array}$ & $\begin{array}{r}13.8 \\
14.8 \\
3.3 \\
0.4\end{array}$ & $\begin{array}{c}77-154 \\
97-193 \\
341-682 \\
688-1,375\end{array}$ & $\begin{array}{c}29.0-58.0 \\
9.9-19.8 \\
4.3-8.6 \\
1.0-2.0\end{array}$ \\
\hline
\end{tabular}

Form 1040 returns only. Thus number of returns with underreporting error in this class differs from the number in Table 21 .

b Includes business returns with adjusted gross income of less than $\$ 7,000$, where gross receipts exceeded $\$ 25,000$.

lower classes. ${ }^{38}$ One way of gauging their importance is to compare the estimated average amount uncovered by the ACP with the average amount of dividends initially reported in each of the four broad income classes. Such a comparison is made in Table $22,{ }^{39}$ which is limited to 1040 returns.

On the average the underreporting error in the two lower income classes was serious. In the under- $\$ 7,000$ class, its value probably ranged between approximately half to almost the whole average amount of

38 "Lower" is defined with reference to the four income classes into which the ACP data are classified, rather than the usual income distributions for which the topmost classes would be close to the upper limits of our "lower" classes.

39 Note that the classifications of major or minor error in dividend reporting is not related to the size of the dividend error, but to its importance relative to all errors made by the taxpayer. More specifically a major dividend error as defined by the ACP "means that (a) the error in dividends ... was responsible for the largest portion of change in adjusted gross income and (b) the change in adjusted gross income was responsible for a larger portion of the tax change than either exemption change, or personal deduction change, or mathematical error." All other dividend errors were classified as minor. The fact that minor errors were at least as large as major errors means that the minor errors occurred on returns generally more error-prone and with a larger total tax change than returns with major errors. 


\section{Dividend Underreporting on Tax Returns}

dividends reported for returns with minor errors in dividends, somewhat below this for returns with major errors. In the income class $\$ 7,000$ to $\$ 25,000$, dividend errors averaged between one-quarter and two-thirds of the average amount reported. In the two upper income classes, judged this way, dividend underreporting errors were much less important-between 1 and 10 per cent. Note also the relatively large average overreporting error (lower half of Table 22), which also declines in importance relative to reported dividends moving up the income scale. This suggests that some of the underreporting of dividends, too, can be laid to carelessness and poor record-keeping rather than purposeful evasion. But this is not the whole story: overreporting errors averaged only half as much as or less than underreporting errors, not to mention the much greater frequency of underreporting errors.40 The number of returns with dividend error and tax decrease was only about 11 per cent of the number of returns with dividend error and tax increase.

This section should not be concluded without some reference to the dividend gap discussed earlier. For 1948 we estimated the gap at about $\$ 260$ million. (This is the variant 2 value which is much lower than the variant I or 3 values.) If we take account of the variance of the gap, it might better be described as falling in the interval of $\$ 190$ to $\$ 330$ million. By reasoning similar to that used earlier for 1958 , about $\$ 100$ million of this might be explained as dividend receipts of those not required to file. (This allows for the $\$ 40$ million reported in classes below the filing requirement.) The rest presumably was pure underreporting. Thus somewhere between $\$ 90$ and $\$ 230$ million were not reported. And our estimate of the aggregate amount of unreported dividends based on the ACP data was between $\$ 90$ and $\$ 179$ million. Thus, the two measures of unreported dividends correspond quite closely. However, were we to use the variant 1 measure of the gap (since, as noted earlier, variant 2 tends for several reasons to understate it), there would be no such close congruence between the gap as we estimate it and aggregate underreporting as estimated from the ACP data. For this latter figure would fall far short of the $\$ 500$ to $\$ 600$ million of nonreported dividends provided for 1948 by variant 1 (adjusted for dividends of those not required to file). Variant 3 also yields a larger figure for the gap than is obtained from the ACP data.

40 The data in Table 21 are net-i.e., the excess of estimated underreported dividends over estimated overreported dividends. 


\section{Dividends Under the Income Tax}

The ACP was designed to discover only the underreported dividends of those who filed tax returns. Some of the difference between our estimates and those derived from the ACP could be due to dividend receipts of persons who intentionally did not file.

\section{THE DATA FOR 1959}

The Internal Revenue Service's interest in dividend reporting (or nonreporting) errors did not, of course, stop with 1948. But no findings of any further investigations it may have undertaken were released until March 1961, when data for 1958 and 1959 were made public. In September 1961 a supplement to the March report based on audited data was released.

For each of these two years a survey of underreporting was made. A random sample of information returns (form 1099 returns which must be filed by corporations for any dividend payment of $\$ 10$ or more) was chosen, and then matched against the recipients' income tax returns to see if the dividends were reported.41 These two surveys are more pertinent than the 1948 data because they represent a more direct estimate of the amount of underreporting and they are more current. But since they are more direct estimates and since they have $\$ 25,000$ and over as their highest income class, they are not strictly comparable with the 1948 data. Moreover, while the sample was randomly chosen from the body of 1099 returns, it is not known to what degree the distribution of 1040 returns determined by the sample of 1099 returns approximates the distribution of all dividend recipients. The 1948 ACP sample was chosen to represent the whole distribution of taxpayers. Therefore we report the 1959 data in their own terms. This does not mean that the findings cannot be compared at all; rather it suggests that only broad comparisons can be made. ${ }^{42}$

The data in Table 23 show the 1959 survey findings on the per-

41 This is a rough statement of the procedure, sufficient for the present purpose, but it glosses over numerous details and technicalities.

42 The description of the sample that follows is drawn from Taxpayer Behavior in the Reporting of Dividends and Interest in Income Tax Returns for 1958 and 1959, a report by Mortimer M. Caplin, Commissioner of Internal Revenue, March 10, 1961. But the data themselves, supplied by the Internal Revenue Service at a later date, are based on the audited survey results, some of which appear in "Supplement to Report on Taxpayer Behavior in the Reporting of Dividends and Interest in Income Tax Returns for 1958 and 1959," Mortimer M. Caplin, Commissioner of Internal Revenue, August 30, 1961. Because only the 1959 survey results were audited, our discussion here is limited to the 1959 data. 
Dividend Underreporting on Tax Returns

TABLE 23

Percentage of Taxpayers in Sample Who Fully Reported Information Document Dividends on Their Income Tax Returns, 1959

(form 1040 returns only)

\begin{tabular}{cc}
\hline \hline $\begin{array}{c}\text { Adjusted Gross } \\
\text { Income Class }\end{array}$ & $\begin{array}{c}\text { Percentage of } \\
\text { Taxpayers }\end{array}$ \\
\hline Under $\$ 5,000$ & 70 \\
$\$ 5,000$ to $\$ 10,000$ & 69 \\
$\$ 10,000$ to $\$ 25,000$ & 73 \\
$\$ 25,000$ and over & 80 \\
Total & 71 \\
\hline
\end{tabular}

Source: Internal Revenue Service. These percentages are based on audited data and are, therefore, not the same as those in Caplin, Taxpayer Behavior.

centage of the total number of dividend recipients in each adjusted gross income class who reported all the dividends accounted for in the information documents. For the whole sample, 71 per cent were full reporters in 1959. Looking for income class differences, one finds that the highest class, $\$ 25,000$ and over, had a higher percentage of full reporters than the others. ${ }^{43}$ The 1959 results, therefore, seem different on this score from the results in column 7 of Table 21, which suggests, except for the lowest income class, substantially the same percentage of underreporters in all income classes.

For 1959, data are also available on the percentage in the sample who reported fully, arrayed by size of reportable dividends. The results, given in Table 24, present a somewhat different picture from that obtained from the income class percentages. For the lowest dividend class has a smaller percentage of full reporters than any other. But since such dividends, if reported, would be excluded from adjusted gross income anyway, it is understandable that there would not be as many full reporters relatively here as in the other dividend classes. The steady rise in the fully reported percentages reaching up the in-

${ }^{43}$ It should be remembered that these surveys' top income class is quite low, given the high concentration of dividends. More pronounced differences in the fully reporting percentage might show up at some point higher in the income scale. The fact that the total percentage was the same as all the low income class percentages does not necessarily preclude this possibility because the dividend recipients this high up would be few in number. 


\section{Dividends Under the Income Tax}

TABLE 24

Percentage of Taxpayers Who Fully Reported Information Document Dividends, by Size of Reportable Dividends, 1959

(form 1040 returns only)

\begin{tabular}{ll}
\hline \hline $\begin{array}{c}\text { Size of Report- } \\
\text { able Dividends }\end{array}$ & $\begin{array}{c}\text { Percentage of } \\
\text { Taxpayers }\end{array}$ \\
\hline Under $\$ 50$ & 55 \\
$\$ 50$ to $\$ 100$ & 69 \\
$\$ 100$ to $\$ 500$ & 72 \\
$\$ 500$ to $\$ 1,000$ & 74 \\
$\$ 1,000$ and over & 75 \\
Total & 71 \\
\hline
\end{tabular}

Source: Internal Revenue Service. These percentages are based on audited data and are, therefore, not the same as those in Caplin, Taxpayer Behavior. Cases where reportable dividends totaled less than $\$ 50$ were not audited since the amount involved was exceeded by the allowable dividend exclusion.

\section{TABLE 25}

Percentage of Information Document Dividends Reported on Income Tax Returns, 1959

(form 1040 returns only)

\begin{tabular}{cc}
\hline \hline $\begin{array}{c}\text { Adjusted } \\
\text { Gross } \\
\text { Income } \\
\text { Class }\end{array}$ & $\begin{array}{c}\text { Percentage } \\
\text { of } \\
\text { Dividends } \\
\text { Reported }\end{array}$ \\
\hline Under $\$ 5,000$ & 92 \\
$\$ 5,000$ to $\$ 10,000$ & 89 \\
$\$ 10,000$ to $\$ 25,000$ & 93 \\
$\$ 25,000$ and over & 98 \\
Total & 95 \\
\hline
\end{tabular}

Source: Internal Revenue Service. These percentages are based on audited data and are, therefore, not the same as those in Caplin, Taxpayer Behavior. 


\section{Dividend Underreporting on Tax Returns}

come scale is consistent enough to be accepted. In the light of the observation in footnote 44, which applies here also, however, the slight difference between the percentages in the $\$ 500$-to- $\$ 1,000$ and $\$ 1,000$ and-over classes suggests that possibly, over some range in the over$\$ 1,000$ class, the percentage dips below 75 and then rises above it further up the dividend size scale.

More pertinent to the problem of this chapter than the number (or percentage) not fully reporting is the amount of dividends not reported that should have been. The surveys' findings on this subject are summarized in Table 25. With the exception of the lowest income class, the results follow a reasonable and familiar pattern, with the reporting percentage rising with income class. ${ }^{44}$

\section{Effect of Voluntary Compliance Campaign on Dividend Gap}

One general conclusion of this chapter has been that a dividend gap of some size which cannot be explained away by imputations to nontaxable institutional and individual stockholders has existed over long periods of time. Many would hold that some remedy is in order. At least three possibilities exist for dealing with the problem: (1) increased auditing of dividend returns, (2) specific reminders that dividend receipts are taxable and notification to the stockholder that information returns on dividend payments to him are in possession of the Internal Revenue Service, ${ }^{45}$ or (3) instituting withholding of tax liability on dividend payments. Evaluation of the administrative feasibility and costs of these possibilities lies beyond the scope of our study. But, with reference to the data in the last section and information of a similar nature, a limited evaluation of the effectiveness of methods (1) and (2) can be made, for since the latter part of 1959, the Treasury Department has consciously sought to improve dividend reporting by these two devices-increased auditing and wider publicity-and has, in addition, on several occasions evaluated the efficacy of these attempts.

In 1959, motivated by a study of the gap for 1956 generally similar to the one described here for 1958, the U.S. Treasury Department in-

44 There are good reasons to hold that the 95 per cent reporting for the whole sample does not permit us to conclude that the dividend gap is only 5 per cent. (See the next section of this chapter.)

45 Currently any dividend payments in excess of $\$ 10$ per annum must be reported to the Internal Revenue Service on form 1099. Many corporations, however, find it simpler to report all such payments no matter how small. 


\section{Dividends Under the Income Tax}

stituted a program to increase voluntary reporting of dividends and interest by taxpayers. The nature of the program and what it appears to have accomplished at an early date are best described by the Department itself. ${ }^{48}$

Following the completion of the 1956 survey, it was determined to take action in two separate areas to improve the reporting of the amounts received by the recipients of dividends and interest. . .

All payers of $\$ 10$ or more in dividends and $\$ 600$ or more of interest must make reports of such payments to the Revenue Service on Form 1099 or other information documents. In every Revenue District a broadened and accelerated program of matching these forms with the returns of individual taxpayers is actively in progress. A vigorous follow-up audit will be made in cases where a return has not been filed or where additional assessments of tax and penalty are indicated by the information secured from the information documents.

The second half of the program to insure proper reporting is the cooperative information program undertaken by the Revenue Service and by the payers of dividends and interest. Many of you participated in this program. More than 75 million special notices were mailed to recipients of dividends and interest. This distribution was supplemented by a coordinated information campaign using newspapers, magazines, radio and television. Excellent cooperation was given in this area by tens of thousands of corporations, banks and individuals active in the dividend and interest field.

Written and oral communications have gone from the national associations to their state and local members urging full cooperation. Articles have been published in association journals, financial journals, monthly newsletters, and other trade publications. Posters have been prepared and distributed. In some areas in this state some of your members joined with other financial institutions in sponsoring newspaper ads on the subject.

We know from the many comments we have received and from the many questions answered by our District Offices during the 1960 filing period, that the voluntary information program has been most successful. It is, of course, somewhat early to appraise fully

46 The following paragraphs are taken from a speech delivered by Under Secretary of the Treasury Fred C. Scribner, Jr., at the Annual Convention of the Maine Bankers' Association, June 24, 1960. 


\section{Dividend Underreporting on Tax Returns}

the extent of the increased reporting of dividends and interest since only a little more than two months has elapsed since the filing date for the returns covering the year 1959.

However, some measure of the program's success has been obtained from checking some 8,000 individual cases selected as the result of a screening of approximately 100,000 cases.

In each of the 8,000 cases the information returns indicated that the taxpayer in the tax year 1958 had received $\$ 300$ or more of dividends and interest. The documents indicated the possibility of a failure on the part of the taxpayer to report in full. We have now received audit reports on 1,340 of the 8,000 cases selected. The number of taxpayers in this group of 1,340 who failed to report dividend income or reported only in part dropped from 777 in 1958 to 407 in 1959, or a decrease of 48 per cent in the number of taxpayers underreporting dividends received. The amount of unreported dividends income from these 777 taxpayers decreased approximately 42 per cent from 1958 to 1959 .

It is our belief that a substantial part of this increase has resulted from the voluntary program of cooperation in the dividend and interest field, coupled as it is with the stepped-up enforcement program. The Treasury Department greatly appreciates the many steps taken by payers of dividends and interest, steps in many instances involving substantial expenditures, to bring to the attention of recipients of dividends and interest income their obligation to report such income fully on their tax returns. . . .

More recent information on the success of the program was reported in The New York Times of October 9, 1960.

On the basis of the admittedly limited sample, Dana Latham, Tax Commissioner, says the educational program has been amazingly successful.

As of last Tuesday, the Treasury had audit reports on 1,801 of the selected cases. The Commissioner said that, based on the 1,801 cases, the number of persons failing to report dividends fully in 1958 decreased by 50 per cent in 1959. The unreported dividend income decreased by 45 per cent.

Following close on the heels of this evidence came some additional information that appeared to confirm that sizable inroads had been made on the dividend gap. The Treasury reported in a press release 


\section{Dividends Under the Income Tax}

dated December 22, 1960, that analysis of the returns for the year 1959 filed during 1960 "show significant increases over the two prior years in the number of returns reporting interest and dividends. There were also sizable increases in the amount of dividends and interest reported." While these were preliminary estimates, the Treasury held that, on the basis of past experience, they were likely to stand at substantially their estimated level. Moreover, the contention was that this improvement indicated "a considerable degree of success for the first year of the Treasury's concerted drive to improve taxpayer reporting of dividend and interest income."

There is no basis for making as refined an estimate of the gap for 1959 as for earlier years since some of the basic data are not yet available. Nonetheless we can project the 1958 data with sufficient assurance to assert that, if the preliminary estimate released in December 1960 for dividends reported on tax returns was correct, then the gap had indeed declined. Making some rough projections and using the preliminary figure for dividends reported by individuals on tax returns of $\$ 10.3$ billion for 1959 , one gets a decline in the gap (very rough of course) on the order of one-half.

Thus, given what was known at the end of 1960, it did appear that the dimensions of the dividend gap were considerably smaller in 1959 than in 1958. We should not, of course, stop with a single value estimate, since, as emphasized above, the gap is most appropriately interpreted as falling within a specified range. But, for reasons that will become clear in the next several paragraphs, this refinement is not necessary.

In essence, what has happened since is that new and more accurate estimates have become available. One such set of data has been alluded to and discussed in the preceding section of this chapter-the random sample of dividend returns (form 1099) matched with personal income tax returns (form 1040) of the dividend recipients. Clearly this latter sample is drawn from a more appropriate universe for measuring underreporting and changes therein than a sample obtained by picking taxpayers for whom "the documents indicated the possibility of a failure on the part of the taxpayer to report in full" in 1958. And this was how the sample for the survey whose results were reported by Under Secretary Scribner in his speech of June 24, 1960, quoted above was obtained. This latter basis of choice partakes of the "regression fallacy." It chooses people who have a given attribute in one year and 


\section{Dividend Underreporting on Tax Returns}

seeks to find to what extent they have that same attribute in the succeeding year. To the degree that the attribute is random, it will not show up as pronouncedly in the second year as in the first.

As pointed out by the present Commissioner of Internal Revenue, Mortimer Caplin, the earlier survey was subject to two limitations that restricted the inferences that could be drawn from it. ${ }^{47}$ In the Commissioner's judgment there was no improvement in reporting between 1958 and 1959. He has concluded that "there was no material change in the degree of compliance of identical taxpayers between 1958 and 1959. The relatively small number of taxpayers who improved in their reporting in 1959, after the educational campaign, was roughly balanced or perhaps even over-balanced, in the case of dividends, by the number whose reporting deteriorated." 48

As regards the aggregate amount of dividends reported by individuals on tax returns, the earlier and tentative estimate of $\$ 10.3$ billion, admittedly less accurate than the estimates prepared for Statistics of Income, should be replaced by the Statistics of Income figure of $\$ 9.7$ billion which has since been released. ${ }^{49}$ In view of this evidence, it seems fairly certain that in 1959 at least, the voluntary compliance campaign had not resulted in a substantial reduction in the absolute amount of dividends not reported.

This may be why the Federal Government has recently turned its attention to another method of improving taxpayer compliance. President Kennedy, in his tax message of April 20, 1961, asked Congress to institute withholding on dividends (and some items of interest). At the time of writing, this is where the matter stands. ${ }^{50}$

On the face of it, the Internal Revenue Service sample survey for

47 . . "First, this tabulation was, in no sense, a survey of a representative sample of taxpayers, but was limited to taxpayers where a relatively large potential tax deficiency for 1958 was anticipated. Second, the methods of selection and audit introduced certain distinct biases into the results, so that we were much more apt to include in the program taxpayers who had improved in their reporting of dividends and interest than taxpayers whose reporting had declined. In short, the program was simply a by-product of our regular audit activity designed to check up on potentially flagrant cases of nonreporting, and to bring in revenue. The results were reported for information purposes, but the study was not designed to provide a measure of the improvement among taxpayers generally in the reporting of dividends and interest." (Commissioner Caplin in his report of March 10, 1961, to Senator Byrd as quoted in President's Tax Message, p. 165.)

48 Supplement to Report, p. 1.

49 Statistics of Income, 1959, Part 1 (preliminary), p. 2.

so A further discussion of these points and estimates of the dividend gap from 1955 through 1959 appears in President's Tax Message. 


\section{Dividends Under the Income Tax}

1959 appears to open our usual measure of the gap to suspicion, since the survey suggests a dividend gap of 5 per cent, while our estimate was 10 per cent for 1958 and should be about the same for 1959. But there are a number of features wherein the two procedures are not comparable. Rather than spell them out, we present Commissioner Caplin's conclusions on this point. ${ }^{51}$

Estimates of the overall nonreporting gap have been made by the Treasury Department, as well as by others, that show the total amounts of dividends and interest omitted from tax returns. Our sample surveys give specific evidence of nonreporting by taxpayers, but cannot be expected to provide overall gap estimates, especially when they are based on a rather small sample. Even though ours was a representative sample, it was based on only 3,000 taxpayers in each survey, in 9 Internal Revenue districts, and it was not a "probability sample" susceptible of being "blown" up to represent all taxpayers.

\section{Summary of Findings on Dividend Underreporting}

We end this chapter with a brief summary of the highlights of our survey of dividend coverage on tax returns, but the numerous qualification and caveats that attach to these findings and have been discussed above must be kept in mind in interpreting the results.

1. In the most recent year for which systematic estimates could be made-1958-a sizable gap existed between the dividends paid out to individuals and fiduciaries and the dividends they reported on tax returns. While the amount of such dividends is difficult to pinpoint, they appear to have run at about $\$ 1.0$ billion in that year, or about 10 per cent of the reportable amount.

2. Not all the dividends that were not reported meant a loss of revenue to the Treasury because some dividends went to those who did not have to file or whose exemptions and deductions exceeded their income and would still have even if they had reported all their dividends. Adjusting as well as possible for these factors, we estimated the revenue loss due to unreported dividends at between $\$ 200$ and $\$ 240$ million in 1958 . This may seem a small amount relative to total personal income tax collections. But the problem is not unimportant.

51 Supplement to Report, p. 6. See note, p. 109, this chapter. 


\section{Dividend Underreporting on Tax Returns}

For unreported income may have repercussions more serious than the revenue loss that is directly traceable to it. Underreported income constitutes one piece of a broader problem. A general feeling that some types of income and some particular groups of taxpayers are not carrying their share of the tax load might undermine the zeal with which many taxpayers police themselves. We emphasize dividend underreporting here because that is what we are studying, but other sources of income are also underreported, some of them more so than dividends.

3. A review of the gap over the twenty-three-year period, 19361958 , did not disclose a tendency for the underreporting of dividends to correct itself over time. During these years, which witnessed a revolutionary conversion of the personal income tax from a levy on very few citizens to one reaching almost every income recipient, the gap has tended to rise in absolute terms and to be relatively about as important near the end of the period as at its beginning.

4. An examination of the year-to-year changes in the dividend gap suggests that its relative size roughly reflects taxpayer response to variations in tax rates, especially tax rate increases. Thus during World War II, the dividend gap rose sharply, whereas it declined as tax rates were reduced in the several years following the war. But for the years since 1950, the evidence does not support the conjecture that higher rates discourage reporting and lower rates encourage it.

5. Estimates from a sample audit undertaken by the Bureau of Internal Revenue of the personal income tax returns for 1948 suggest that the most serious underreporting is found among dividend recipients with incomes of less than $\$ 25,000$. Although, of course, particular individuals with higher incomes may underreport significantly, on the whole total underreporting at the higher incomes is not great, and, in any event, is more likely to be discovered. A more recent sample survey by the IRS for 1959 confirms this pattern.

6. Dividends, of course, do not stand alone as regards underreporting. Estimates made for other sources of income also show a gap. While subject to wide margins of error and not strictly comparable, evidence of other sources of income underreporting rounds out the discussion of dividend underreporting. For 1957, the following reporting percentages have been found (source reference appears earlier in this chapter): 


\section{Dividends Under the Income Tax}

$\begin{array}{ll}\text { Wages and salaries } & 97 \% \\ \text { Dividends } & 91.5 \% \\ \text { Business and professional } & \\ \quad \text { proprietors' income } & 81 \% \\ \text { Interest } & 63 \% \\ \text { Farm operators' income } & 45 \%\end{array}$

The sharp differences in coverage percentages creates a presumption that this ranking, although not the estimated percentages, is very likely correct.

\section{Technical Note}

This note explains in detail some of the estimating procedures and tests used in developing the data of Chapter 2. It has four sections covering the following topics: (1) derivation of the dividend gap; (2) specifying the range of the gap and testing year-to-year changes for significance; (3) estimates of the amount of dividend underreporting as disclosed by the ACP, 1948 (Table 21); and (4) estimating the revenue gain from full correction of dividend underreporting.

\section{DERIVATION OF DIVIDEND GAP}

Table 26 presents the adjustments made in each year, while the accompanying notes explain how the entries were estimated.

RANGE OF DIVIDEND GAP AND TESTING YEAR-TO-YEAR CHANGES

\section{A Confidence Interval for the Gap}

$\boldsymbol{R}=$ Dividends of individuals and fiduciaries accounted for on tax returns (line 4 of Table 26).

$M=$ Maximum estimate of dividends reportable by individuals and fiduciaries (line 14 of Table 26).

$G=M-R=$ Dividend gap (line 15 of Table 26).

Each of the components that make up $R$, lines 1,2 , and 3 of Table 26 , are subject to sampling variability. That is to say, each of the components of $R$ is a random variable as is, therefore, $R$ itself. Likewise, most of the components of $M$ are subject to sampling variability; hence $M$ is a random variable. And since $G=M-R, G$ too is a random variable. The observed (estimated) $M$ and $R$ are drawn from a universe of values. If numerous estimates of the lines of Table 26 were undertaken, every time the components of $M$ and $R$ were esti- 


\section{Dividend Underreporting on Tax Returns}

mated we would obtain a different value for each one, a different value for $M$ and $R$, and consequently a different value for $G$. Knowing the sampling variabilities of these components, we can state an interval which will cover $G$ (i.e., within which $G$ will fall) to any desired likelihood. For example, for the confidence interval associated with a .99 likelihood, one could assert that 99 times out of 100 this interval will cover the "true" gap. The "true" gap, of course, is not a random variable; our observed gap is.

The "model" neglecting nonrandom errors of measurement is this:

1. $M=M^{\prime}+\epsilon$, where $M$ is the observed value, $M^{\prime}$ is the "true" value, and $\epsilon$ is a sampling error with a mean of 0 and variance $\sigma^{2}$ to be determined from sampling variability of the components of $M$.

2. $R=R^{\prime}+\nu$, again $R$ is the observed (or estimated) value, $R^{\prime}$ is the "correct" value, and $\nu$ a sampling error with a mean 0 and variance $\sigma^{2}$.

3. $G=M-R=M^{\prime}+\epsilon-R^{\prime}-\nu$.

Let $E()$ indicate the expected value.

4. $E(G)=E(M)-E(R)=E\left(M^{\prime}\right)+E(\epsilon)-E\left(R^{\prime}\right)-E(\nu)$. Since $M^{\prime}$ and $R^{\prime}$ are given numbers, their expected value is $M^{\prime}$ and $R^{\prime}$ respectively, while $E(\epsilon)=E(\nu)=0$. Therefore $E(G)=M^{\prime}-R^{\prime}$.

Let $\sigma^{2}$ be the variance.

5. $\sigma_{G}^{2}=\sigma_{M}^{2}+\sigma_{R}^{2}=\sigma_{M}^{2}+\sigma_{\epsilon}^{2}+\sigma_{R}^{2}+\sigma_{\nu}^{2}$. Since $M^{\prime}$ and $R^{\prime}$ are given numbers, $\sigma_{M^{\prime}}^{2}=\sigma_{R^{\prime}}^{2}=0$. Therefore, $\sigma_{G}^{2}=\sigma_{\epsilon}^{2}+\sigma_{\nu}^{2}$, if, as is the case, $\epsilon$ and $\nu$ are independent.

6. $\sigma_{G}=\sqrt{\sigma_{e}^{2}+\sigma_{\nu}^{2}}$ and the confidence interval within which the true gap will lie 95 times out of 100 is equal to $G \pm 1.96 \sigma_{G}$; while the confidence interval within which the true gap will lie 99 times out of 100 is equal to $G \pm 2.57 \sigma_{G}$.

Estimates of the sampling variabilities of the components that are predominant in determining $\sigma_{G}$ were made available by Ernest C. Engquist, $\mathrm{Jr}$. of the Internal Revenue Service. Notice how $\sigma_{R}^{2}$, which is item 1 in the table dominates the results.

\section{Testing for Significance of Year-to-Year Changes in the Gap}

Define a new random variable, $G_{2}-G_{1}$, which is the change in the gap between any two years, usually between one year and the next.

7. $\sigma_{G_{2}-G_{1}}^{2}=\sigma_{G_{2}}^{2}+\sigma_{G_{1}}^{2}$, and $\sigma_{G_{2}-G_{1}}=\sqrt{\sigma_{G_{2}}^{2}+\sigma_{G_{1}}^{2}}$.

With this standard deviation, we can test for a significant change in the gap between year 1 and year 2 . For we can set up the null hypo- 


\section{Dividends Under the Income Tax}

TABLE

Derivation of Dividends Not

(million

\begin{tabular}{|c|c|c|c|c|}
\hline & & 1936 & 1937 & 1938 \\
\hline & $\begin{array}{l}\text { 1. Dividends reported by individuals on personal } \\
\text { income tax returns }\end{array}$ & 3,174 & 3,188 & 2,212 \\
\hline Plus & 2. Dividends included in "other income" on $1040 \mathrm{~A}$ & & & \\
\hline & or $\mathrm{W}-2$ returns & - & - & - \\
\hline \multirow[t]{4}{*}{ Plus } & 3. Dividends of fiduciaries (estates and trusts) & & & \\
\hline & Variant 1 & 617 & 617 & 454 \\
\hline & Variant 2 & 860 & 860 & 626 \\
\hline & Variant 3 & 一 & - & - \\
\hline \multirow[t]{5}{*}{ Equals } & $\begin{array}{l}\text { 4. Dividends of individuals and fiduciaries ac- } \\
\text { counted for on tax returns }\end{array}$ & & & \\
\hline & Variant 1 & 3,791 & 3,805 & 2,666 \\
\hline & Variant 2 & 4,034 & 4,048 & 2,838 \\
\hline & Variant 3 & - & - & - \\
\hline & 5. Dividends paid by domestic corporations & 7,379 & 7,514 & 5,013 \\
\hline Minus & 6. Intercorporate dividends & 2,677 & 2,682 & 1,791 \\
\hline Plus & 7. Dividends received by individuals from abroad & 44 & 56 & 80 \\
\hline Minus & 8. Dividends paid to foreigners & 220 & 264 & 160 \\
\hline Minus & 9. Dividends received by nonprofit organizations & 97 & 103 & 71 \\
\hline Minus & 10. Dividends received by noninsured pension funds & 12 & 13 & 9 \\
\hline Minus & $\begin{array}{l}\text { 11. Capital gains dividends (paid out by investment } \\
\text { trusts) }\end{array}$ & 20 & 10 & 10 \\
\hline \multirow{4}{*}{$\begin{array}{l}\text { Minus } \\
\text { Minus }\end{array}$} & 12. Dividends included in partnership income & 24 & 25 & 17 \\
\hline & 13. Nontaxable dividends & & & \\
\hline & Variant 1 & 63 & 64 & 44 \\
\hline & Variant 2 & 67 & 69 & 47 \\
\hline & Variant 3 & - & - & - \\
\hline \multirow[t]{12}{*}{ Equals } & $\begin{array}{l}\text { 14. Maximum estimate of dividends reportable by } \\
\text { individuals and fiduciaries (estates and trusts) }\end{array}$ & & & \\
\hline & Variant 1 & 4,310 & 4,409 & 2,991 \\
\hline & Variant 2 & 4,306 & 4,404 & 2,988 \\
\hline & Variant 3 & - & 一 & - \\
\hline & 15. Dividend gap (line 14 minus line 4 ) & & & \\
\hline & Variant 1 & 519 & 604 & 325 \\
\hline & Variant 2 & 272 & 356 & 150 \\
\hline & Variant 3 & - & - & - \\
\hline & 16. Relative dividend gap (line $15 \div$ line 14 ) times 100 & & & \\
\hline & Variant 1 & 12.0 & 13.7 & 10.9 \\
\hline & Variant 2 & 6.3 & 8.1 & 5.0 \\
\hline & Variant 3 & - & - & - \\
\hline
\end{tabular}




\section{Dividend Underreporting on Tax Returns}

26

Reported on Tax Returns, 1936-1958

dollars)

\begin{tabular}{|c|c|c|c|c|c|c|c|c|}
\hline 1939 & 1940 & 1941 & 1942 & 1943 & 1944 & 1945 & 1946 & 1947 \\
\hline 2,544 & 2,999 & 3,299 & 2,833 & 2,780 & 2,986 & 3,010 & 3,674 & 4,295 \\
\hline 一 & - & 109 & 151 & 97 & 15 & 16 & 18 & 15 \\
\hline 555 & 629 & 643 & 558 & 579 & 623 & 674 & 766 & 912 \\
\hline 747 & 791 & 821 & 824 & 848 & 888 & 889 & 1,100 & 1,229 \\
\hline- & 781 & 901 & 669 & 750 & 716 & 895 & 1,071 & 1,140 \\
\hline 3,099 & 3,628 & 4,051 & 3,542 & 3,456 & 3,624 & 3,700 & 4,458 & 5,222 \\
\hline 3,291 & 3,790 & 4,229 & 3,808 & 3,725 & 3,889 & 3,915 & 4,792 & 5,539 \\
\hline - & 3,780 & 4,309 & 3,653 & 3,627 & 3,717 & 3,921 & 4,763 & 5,450 \\
\hline 5,747 & 6,089 & 6,701 & 5,607 & 5,728 & 6,057 & 6,081 & 7,497 & 8,365 \\
\hline 1,906 & 2,021 & 2,235 & 1,344 & 1,334 & 1,429 & 1,418 & 1,713 & 1,882 \\
\hline 68 & 70 & 58 & 51 & 57 & 50 & 47 & 64 & 72 \\
\hline 193 & 187 & 185 & 160 & 154 & 161 & 163 & 200 & 211 \\
\hline 87 & 92 & 101 & 97 & 100 & 106 & 106 & 159 & 196 \\
\hline 11 & 11 & 13 & 12 & 13 & 13 & 14 & 24 & 33 \\
\hline 8 & 8 & 9 & 6 & 8 & 20 & 46 & 73 & 58 \\
\hline 20 & 22 & 24 & 24 & 25 & 27 & 27 & 41 & 55 \\
\hline 51 & 60 & 67 & 61 & 57 & 57 & 58 & 57 & 59 \\
\hline 55 & 62 & 70 & 66 & 63 & 62 & 62 & 61 & 63 \\
\hline- & 62 & 71 & 63 & 60 & 59 & 62 & 61 & 62 \\
\hline 3,539 & 3,758 & 4,125 & 3,954 & $\begin{array}{l}4,094 \\
4088\end{array}$ & 4,294 & 4,296 & 5,294 & $\begin{array}{l}5,943 \\
5,939\end{array}$ \\
\hline 3,535 & 3,756 & 4,122 & 3,949 & 4,088 & 4,289 & 4,292 & 5,290 & 5,939 \\
\hline- & 3,756 & 4,121 & 3,952 & 4,091 & 4,292 & 4,292 & 5,290 & 5,940 \\
\hline 440 & 130 & 74 & 412 & 638 & 670 & 596 & 836 & 721 \\
\hline 244 & -34 & -107 & 141 & 363 & 400 & 377 & 498 & 400 \\
\hline 一 & -24 & -188 & 299 & 464 & 575 & 371 & 527 & 490 \\
\hline 12.4 & 3.5 & 1.8 & 10.4 & 15.6 & 15.6 & 13.9 & 15.8 & 12.1 \\
\hline 6.9 & -0.9 & -2.6 & 3.6 & 8.9 & 9.3 & 8.8 & 9.4 & 6.7 \\
\hline - & -0.6 & -4.6 & 7.6 & 11.3 & 13.4 & 8.6 & 10.1 & 8.2 \\
\hline
\end{tabular}

(continued) 
TABLE 26

\begin{tabular}{|c|c|c|c|c|}
\hline & & 1948 & 1949 & 1950 \\
\hline & $\begin{array}{l}\text { 1. Dividends reported by individuals on personal } \\
\text { income tax returns }\end{array}$ & 4,971 & 5,246 & 6,158 \\
\hline Plus & 2. Dividends included in "other income" on $1040 \mathrm{~A}$ & & & \\
\hline & or $W-2$ returns & 12 & 10 & 9 \\
\hline \multirow[t]{4}{*}{ Plus } & 3. Dividends of fiduciaries (estates and trusts) & & & \\
\hline & Variant 1 & 993 & 915 & 1,330 \\
\hline & Variant 2 & 1,357 & 1,391 & 1,701 \\
\hline & Variant 3 & 1,185 & 1,209 & 1,583 \\
\hline \multirow[t]{5}{*}{ Equals } & $\begin{array}{l}\text { 4. Dividends of individuals and fiduciaries ac- } \\
\text { counted for on tax returns }\end{array}$ & & & \\
\hline & Variant 1 & 5,976 & 6,171 & 7,497 \\
\hline & Variant 2 & 6,340 & 6,647 & 7,868 \\
\hline & Variant 3 & 6,168 & 6,465 & 7,750 \\
\hline & 5. Dividends paid by domestic corporations & 9,386 & 9,569 & 11,553 \\
\hline Minus & 6. Intercorporate dividends & 2,194 & 2,162 & 2,460 \\
\hline Plus & 7. Dividends received by individuals from abroad & 77 & 85 & 91 \\
\hline Minus & 8. Dividends paid to foreigners & 233 & 248 & 285 \\
\hline Minus & 9. Dividends received by nonprofit organizations & 234 & 232 & 302 \\
\hline Minus & 10. Dividends received by noninsured pension funds & 44 & 47 & 65 \\
\hline \multirow[t]{2}{*}{ Minus } & 11. Capital gains dividends (paid out by investment & & & \\
\hline & trusts) & 35 & 30 & 45 \\
\hline Minus & 12. Dividends included in partnership income & 58 & 57 & 67 \\
\hline \multirow[t]{4}{*}{ Minus } & 13. Nontaxable dividends & & & \\
\hline & Variant 1 & 61 & 61 & 60 \\
\hline & Variant 2 & 65 & 66 & 63 \\
\hline & Variant 3 & 63 & 64 & 63 \\
\hline \multirow[t]{12}{*}{ Equals } & $\begin{array}{l}\text { 14. Maximum estimate of dividends reportable by } \\
\text { individuals and fiduciaries (estates and trusts) }\end{array}$ & & & \\
\hline & Variant 1 & 6,604 & 6,817 & 8,360 \\
\hline & Variant 2 & 6,600 & 6,812 & 8,357 \\
\hline & Variant 3 & 6,602 & 6,814 & 8,357 \\
\hline & 15. Dividend gap (line 14 minus line 4 ) & & & \\
\hline & Variant 1 & 628 & 646 & 863 \\
\hline & Variant 2 & 260 & 165 & 489 \\
\hline & Variant 3 & 434 & 349 & 607 \\
\hline & 16. Relative dividend gap (line $15 \div$ line 14 ) times 100 & & & \\
\hline & Variant 1 & 9.5 & 9.5 & 10.3 \\
\hline & Variant 2 & 3.9 & 2.4 & 5.9 \\
\hline & Variant 3 & 6.6 & 5.1 & 7.3 \\
\hline
\end{tabular}


Dividend Underreporting on Tax Returns

(concluded)

\begin{tabular}{|c|c|c|c|c|c|c|c|}
\hline 1951 & 1952 & 1953 & 1954 & 1955 & 1956 & 1957 & 1958 \\
\hline 6,056 & 5,860 & 5,828 & 7,269 & 8,100 & 8,892 & 9,432 & 9,058 \\
\hline 8 & 6 & 5 & 6 & 3 & 3 & 3 & 3 \\
\hline 1,331 & 1,393 & 1,377 & 331 & 320 & 309 & 313 & 317 \\
\hline 1,660 & 1,650 & 1,721 & 368 & 362 & 356 & 366 & 375 \\
\hline 1,516 & - & - & - & - & - & - & - \\
\hline $\begin{array}{l}7,395 \\
7,724\end{array}$ & $\begin{array}{l}7,259 \\
7,516\end{array}$ & $\begin{array}{l}7,210 \\
7,554\end{array}$ & $\begin{array}{l}7,606 \\
7,643\end{array}$ & $\begin{array}{l}8,423 \\
8,465\end{array}$ & $\begin{array}{l}9,204 \\
9,251\end{array}$ & $\begin{array}{l}9,748 \\
9,801\end{array}$ & $\begin{array}{l}9,378 \\
9,436\end{array}$ \\
\hline 7,580 & - & - & - & - & - & - & - \\
\hline 11,299 & 11,263 & 11,601 & 11,913 & 13,592 & 14,498 & 14,914 & 14,952 \\
\hline 2,377 & 2,350 & 2,389 & 2,332 & 2,572 & 2,688 & 2,681 & 2,829 \\
\hline 92 & 85 & 108 & 115 & 140 & 165 & 176 & 179 \\
\hline 286 & 299 & 320 & 305 & 357 & 378 & 401 & 413 \\
\hline 320 & 338 & 330 & 390 & 455 & 488 & 505 & 501 \\
\hline 69 & 99 & 131 & 192 & 210 & 262 & 338 & 402 \\
\hline 87 & 102 & 83 & 162 & 276 & 365 & 346 & 327 \\
\hline 62 & 56 & 55 & - & - & - & - & - \\
\hline 60 & 63 & 65 & 70 & 71 & 76 & 110 & 230 \\
\hline 62 & 65 & 68 & 70 & 71 & 77 & 112 & 230 \\
\hline 62 & - & - & - & - & - & - & - \\
\hline 8,130 & 8,041 & 8,336 & 8,577 & 9,791 & 10,406 & 10,709 & 10,429 \\
\hline 8,128 & 8,039 & 8,333 & 8,577 & 9,791 & 10,405 & 10,707 & 10,429 \\
\hline 8,128 & - & - & - & - & - & - & - \\
\hline 735 & 782 & 1,126 & 971 & 1,368 & 1,202 & 961 & 1,051 \\
\hline 404 & 523 & 779 & 934 & 1,326 & 1,154 & 906 & 993 \\
\hline 548 & - & - & - & - & - & 一 & - \\
\hline 9.0 & 9.7 & 13.5 & 11.3 & 14.0 & 11.6 & 9.0 & 10.0 \\
\hline 5.0 & 6.5 & 9.3 & 10.9 & 13.5 & 11.1 & 8.5 & 9.5 \\
\hline 6.7 & - & - & - & - & - & - & - \\
\hline
\end{tabular}




\section{Dividends Under the Income Tax}

\section{Notes to Table 26}

Line 1: As tabulated annually in Statistics of Income, Part 1. For 1944 and 1945, when a combined dividend and interest figure was reported, dividends were estimated on the basis of the 1946 ratio of dividends to dividends and interest combined.

Line 2: Estimated for 1944-1956. by taking dividends and interest to be half of wages and salaries not withheld on and dividends and interest of under $\$ 100$ on form W-2 or 1040A returns as given in a footnote to table 2 of Statistics of Income, Part 1 (cf. Selma Goldsmith, "Appraisal of Basic Data Available for Constructing Income Size Distribution," in Studies in Income and Wealth, 13, pp. 360-361), and then applying to this figure the fraction that dividends constituted of dividends plus interest for all returns under $\$ 5,000$ as tabulated in Statistics of Income. For 1957 and 1958, arbitrarily put at $\$ 3$ million.

Estimated for 1941-1943 by applying the ratio of dividends to total property income (of specified types) on 1040 returns to the property income component of $1040 \mathrm{~A}$ returns.

Line 3: Variant 1, 1936-1953: Sum of (a) dividend component of individual income from estates and trusts and (b) dividends retained by fiduciaries. Value for (a) is estimated annually by applying ratio of dividends to total income of taxable fiduciaries to income from estates and trusts reported by individuals. Value for (b) is estimated by applying the same ratio used for (a) to the retained income of fiduciaries. For 1944 and 1945, dividends are estimated from combined dividend and interest totals on basis of 1946 percentages.

1954-1958: Starting in 1954, dividend component of individual income from estates and trusts is reported under dividends and shows up in line 1 total. Value for (b) is estimated from tabulations for fiduciaries in 1954 and 1956 as sum of excluded dividends, fiduciaries share of dividend tax credit blown up to its dividend equivalent, and an adjustment to take account of dividends not eligible for exclusion and credit. For 1954, two additional adjustments are needed: (1) Because only 92 per cent of returns were filed on new basis of IRC of 1954 (this being a transitional year), the tabulated dividend total was assumed to be only 92 per cent of correct figure and was adjusted accordingly; (2) credit was applied to dividends received after July 1, 1954, and tabulated credit was raised on this basis to a full year's equivalent. 1955 and 1957 values were obtained by interpolating between 1954 and 1956 and 1956 and 1958, respectively.

Variant 2: Dividends of taxable and nontaxable fiduciaries as tabulated in Statistics of Income, 1937, 1938, 1939, and 1952. Assumed same in 1936 as 1937. Estimated for 1940-1951 on the basis of interpolation between 1939 and 1952 percentage that dividends of fiduciaries represented of NID personal dividend receipts. 1953 estimated by interpolation between similar percentages for 1952 and 1954. From 1954 on, same as variant 1 above with addition of dividend component of fiduciary charitable contributions estimated by applying fraction dividends comprised of total fiduciary income to charitable contributions of fiduciaries. For 1944 and 1955, dividend figure was broken out of combined dividend and interest total by applying 1946 ratio.

Variant 3: Applies only for 1940-1951. Derived by applying values obtained by interpolating between the 1939 and 1952 ratios of dividends of taxable fiduciaries to total fiduciary dividends to the dividends of taxable fiduciaries as tabulated in Statistics of Income. 1944 and 1945 dividends were separated out from combined dividend and interest tabulation by using ratio for 1946.

Line 5: From Statistics of Income, Part 2, for each year.

Line 6: Same as line 5.

Line 7: Data that served as basic estimates were supplied by Samuel Pizer, U.S. Department of Commerce. For 1946-1958, equals dividend receipts on other investments plus 5 per cent of dividend receipts on direct investments (total investments 


\title{
Dividend Underreporting on Tax Returns
}

\author{
Notes to TABLE 26 (continued)
}

abroad equal direct plus other) blown up by division by .85 to get amount before withholding. In getting the estimate for 1945-1936, the 1946 estimate was computed as a percentage of total dividend receipts on foreign investment and again blown up by dividing by 85 .

Line 8: As in line 7, basic data were supplied by Samuel Pizer. To his estimates of dividend payments to foreigners (which were net of tax), we added estimated tax withheld as supplied again by National Income Division, Department of Commerce, up through 1954, applying the 1954 percentage of tax withheld to get the remaining years.

9. Estimated by applying to net dividends (line 5 minus line 6) the ratio of nonprofit organization stockholdings to total stockholdings (net of corporate holdings). For 1936-1944 total stockholdings were estimated by Raymond Goldsmith (Table F-4 of Appendix F of Financial Intermediaries in the American Economy since 1900, Princeton for NBER, 1958) for benchmark dates 1933, 1939, and 1945, and interpolated for the other years in the period; for 1945-1955, estimates were provided by Morris Mendelson from the National Bureau Postwar Capital Markets study. For 1936-1949, nonprofit organization stockholdings were estimated by Raymond Goldsmith ( $A$ Study of Saving in the United States, Vol. III, Princeton, 1956, pp. 450, 452) for benchmark dates 1933,1939, 1945, and 1949 and interpolated for the other years in the period; for 1950 and 1951, similarly estimated on basis of Goldsmith's 1949 figure and estimate for 1952 in Morris Mendelson, The Flow-of-Funds Through the Financial Markets, 1953-1955, Working Memorandum, New York, NBER, 1959; for 1953-1955, from this same source. For 1956-1958, the 1956 percentage of total stockholdings was used.

Line 10: For 1936-1951, estimated in essentially the same manner as line 9. Stockholdings of pension funds for 1939, 1945, and 1949, from Goldsmith's Financial Intermediaries Table A-10, and for 1952 from Mendelson's Flow-of-Funds; for the remaining years, estimated by interpolation using the values for these four years and 1933. For 1952-1958, estimated as follows from data in SEC, "Corporate Pension Funds," annual releases: yield figures were applied to the pension fund bondholdings and the estimated interest receipts were subtracted from the total of interest and dividends received by pension funds. The dividend figure thus obtained was raised by 5 per cent to take account of omissions in the coverage of the SEC survey.

Line 11: Estimates for 1953-1958 were derived by taking the data of the National Association of Investment Companies (as published in Investment Companies, A Statistical Summary, 1940-1959) as 96 per cent of the total according to New York Stock Exchange estimates by Stan West and Milton Leontiades, who explain: "The NAIC membership represents about $96 \%$ of the assets of open-end investment companies and about one-third of closed-end investment companies' and holding companies' assets. However, the remaining two-thirds of closed-end investment and holding companies are principally represented by the holdings of Christiana Securities and Delaware Realty Company, both of which maintain stable security portfolios and thus do not distribute capital gains."

Estimates for 1952-1939 were obtained by computing percentage that 1953 estimate above comprised of the average of 1953 and 1952 realized net long-term gains of holding and other investment companies as published in Statistics of Income, Part 2; applying this percentage to average of each year and the year before it, i.e., year $x+1$ and year $x$; and attributing estimate thus obtained to year $x+1$.

Estimates for years 1936-1938 are guesses based on a "reasonable" relation to 1939.

Line 12: Values for 1939, 1945, 1947, and 1953 are from special supplements to Statistics of Income. For all other years between 1936 and 1953, estimates were obtained by interpolation using dividends of partnerships as a percentage of the sum of lines $5,6,7$, and 8 . 


\title{
Dividends Under the Income Tax
}

\author{
Notes to TABLE 26 (concluded)
}

Line 13: Estimates for 1956-1958 were obtained from all reported nontaxable dividends in the Commerce Clearing House's Capital Changes Reporter (tabulations therefrom generously made available by Stan West and Milton Leontiades) increased by 10 per cent for small companies not reported on. The 1958 figure includes the dividend of "tax-option" corporations which elected to be taxed as partnerships as tabulated in Statistics of Income.

Similarly, tabulations were made from the Capital Changes Reporter, with $\$ 100,000$ added for each company noted for which no dividend data were available, and increased by 10 per cent for 1941, 1946, and 1951 .

Estimates for 1952-1955 were obtained by interpolation between 1951 and 1956 values. Estimates for 1941-1950 were taken to be the figure for each year that seemed the most reasonable on the basis of the tabulated 1941, 1946, and 1951 totals.

Estimates for 1940-1936 were derived by applying the 1941 percentage for nontaxable dividends to total net dividends (line 5 minus line 6 ). This procedure gives about the same figures as applying the 1941 percentage of nontaxable dividends to dividends of investment, etc., companies which in this period were the main payers of nontaxable dividends.

Three variant measures for nontaxable dividends represent the triumph of principle over pragmatism. For, in principle, such dividends go to all stockholding entities, and to individuals and fiduciaries one should impute only a fraction of all nontaxable dividends. We carried out this principle, in relation to net domestic dividends (the sum of lines $5,6,7$, and 8 ) for the three variant measures of dividends of individuals and fiduciaries even though it turned out, in practice, to constitute a numerically unimportant refinement.

thesis, i.e., assert that the difference in the gap between these two years is equal to zero; and depending on the level of significance deemed relevant, we can accept or reject the hypothesis.

Let $H_{0}$ designate the null hypothesis.

8. $H_{0}: G_{2}-G_{1}=0$ or $G_{2}=G_{1}$.

To test this hypothesis, we measure the normal deviate $Z$ where,

$$
Z=\frac{G_{2}-G_{1}}{\sqrt{\frac{\sigma_{G_{2}}^{2}+\sigma_{G_{1}}^{2}}{2}}}
$$

If we choose a .05 level of significance, $Z$ must be equal to or greater than $|1.96|$ for the null hypothesis to be rejected, i.e., for the change in the gap between these two years to be considered statistically significant. If a .01 level of significance is chosen, the null hypothesis will be rejected only if $Z \geqq|2.57|$.

This test was applied to every year-by-year change in the gap for variants 1 and 2. Almost all such changes were significant except as noted in Table 17. We also tested by the same method the difference between the average gap for 1937-1939 and for 1956 and 1958. The 


\section{Dividend Underreporting on Tax Returns}

TABLE 27

Values of $Z_{1}$ and $Z_{2}$ for Year-to-Year Changes in the Gap, 1936-1958

\begin{tabular}{lrrrrr}
\hline \hline $\begin{array}{c}\text { Change } \\
\text { Between }\end{array}$ & \multicolumn{1}{c}{$Z_{1}$} & \multicolumn{1}{c}{$Z_{2}$} & $\begin{array}{c}\text { Change } \\
\text { Between }\end{array}$ & \multicolumn{1}{c}{$Z_{1}$} & \multicolumn{1}{c}{$Z_{2}$} \\
\hline $1936-1937$ & 3.18 & 3.15 & $1947-1948$ & -2.38 & -3.59 \\
$1937-1938$ & -12.08 & -8.92 & $1948-1949$ & 0.42 & -2.21 \\
$1938-1939$ & 5.72 & 4.68 & $1949-1950$ & 4.52 & 6.75 \\
$1939-1940$ & -13.25 & -11.88 & $1950-1951$ & -2.46 & -1.63 \\
$1940-1941$ & -2.08 & -2.71 & $1951-1952$ & 0.81 & 2.05 \\
$1941-1942$ & 12.61 & 9.25 & $1952-1953$ & 6.23 & 4.86 \\
$1942-1943$ & 9.19 & 9.02 & $1953-1954$ & -3.23 & 1.54 \\
$1943-1944$ & 1.30 & 1.50 & $1954-1955$ & 5.75 & 5.68 \\
$1944-1945$ & -2.92 & -0.91 & $1955-1956$ & -2.18 & -2.26 \\
$1945-1946$ & 8.48 & 4.28 & $1956-1957$ & -3.44 & -3.54 \\
$1946-1947$ & -3.38 & -2.88 & $1957-1958$ & 1.54 & 1.49 \\
\hline
\end{tabular}

difference, of course, was significant. Table 27 shows the values of $Z$, where $Z_{1}$ applies to variant $\mathrm{I}$ and $Z_{2}$ to variant 2 .

In making these tests, as already noted, the variance associated with dividends reported by individuals was by far the most important component of the total variance.

\section{ESTIMATES OF DIVIDEND UNDERREPORTING BASED ON ACP DATA}

The estimates of dividend underreporting in Tables 21 and 22 are based on tabulations of the ACP data made available by the Internal Revenue Service in 1951. We describe the estimates incorporated in Table 21.

The estimate of underreporting must be made as a range rather than a single value because, with only the total tax change reported for returns with dividend errors, it was necessary arbitrarily to assign fractions of that total to the dividend error alone. In the ACP tabula. tions dividend errors were classified as major or minor errors. All returns that met the following conditions were placed in the major error category.

1. The error in dividends accounted for the largest portion of the change in adjusted gross income, i.e., the addition (or subtraction) due to audit.

2. The change in adjusted gross income was responsible for a bigger fraction of the total tax change than exemption or deduction changes, or mathematical error. 


\section{Dividends Under the Income Tax}

All other returns with dividend errors were placed in the minor error category.

Following this classification, we set up three possibilities for major error returns: 100,75 , and 50 per cent of the total tax change due to the dividend error; and three percentage assumptions for minor error returns: 40,30 , and 20 per cent. In every case we estimated the dividends not covered by the ACP by dividing the tax change assumed due to the errors in dividend reporting by the marginal rate that applied on the average to all taxpayers (taken from Statistics of Income) in each of the broad income classes by which the ACP data were tabulated and for joint and separate returns.

The lower value of the estimates in Table 21 is the sum of the 50 per cent for major errors and 25 per cent for minor error assumptions; the upper values of the range come from adding the results of the 100 and 40 per cent assumptions. The upper value of the range is almost surely above the actual figure, but it cannot be stated as positively that the lower limit of our range is below the real value.

Table 22 is derived from 21 and data from Statistics of Income.

\section{ESTIMATING REVENUE GAIN FROM FULL CORRECTION OF DIVIDEND UNDERREPORTING IN 1958}

From Table 21 we derived the income class distribution of dividend underreporting, applied these percentages to our estimated increment to the tax base of $\$ 900$ million that would follow elimination of underreporting, and multiplied the amounts thus obtained by the marginal rates (weighted by the proportion of joint and separate returns) that applied to the taxable income in each of the broad adjusted gross income classes. Having the data conveniently at hand, we assumed that the 1956 marginal rates applied in 1958, hardly a drastic assumption.

A numerical summary of our procedure follows in Table 28.

\section{Note on Difference Between Aggregate Gap and Survey Gap}

Earlier it was asserted that our 10 per cent gap and the 1959 Survey's 5 per cent were not necessarily inconsistent. More correctly, using a .99 confidence interval, our gap of 9 to 11 per cent ( 8.5 to 10.5 under variant 2) is not necessarily in conflict with the Survey's 2.5 to 7.5 per cent gap. For the two sets of estimates are not comparable in many ways.

Rather than elaborate on all these differences, we note here the Survey features that might tend to understate the gap. For one thing, 
TABLE 28

Estimated Revenue Loss Due to Dividend Underreporting in 1958

\begin{tabular}{|c|c|c|c|c|c|c|}
\hline \multirow[b]{2}{*}{$\begin{array}{l}\text { Adjusted Gross } \\
\text { Income Class } \\
\text { (1) }\end{array}$} & \multirow{2}{*}{$\begin{array}{l}\text { Percentage of } \\
\text { Total Under- } \\
\text { reporting in } \\
\text { Each Class } \\
\text { (2) }\end{array}$} & \multirow{2}{*}{$\begin{array}{l}\$ 650 \\
\text { Million } \\
\text { Allocated } \\
\text { by \% in } \\
\text { Col. } 2 \\
\text { (3) }\end{array}$} & \multirow{2}{*}{$\begin{array}{l}\$ 850 \\
\text { Million } \\
\text { Allocated } \\
\text { by \% in } \\
\text { Col. } 2 \\
(4)\end{array}$} & \multirow{2}{*}{$\begin{array}{l}\text { Weighted- } \\
\text { Average } \\
\text { Marginal } \\
\text { Rate } \\
\text { (per cent) } \\
\quad(5)\end{array}$} & \multicolumn{2}{|c|}{ Revenue Gain } \\
\hline & & & & & $\begin{array}{c}\text { Low } \\
\text { Estimate } \\
(6)\end{array}$ & $\begin{array}{c}\text { High } \\
\text { Estimate } \\
(7)\end{array}$ \\
\hline Under $\$ 7,000$ & 34.5 & $\$ 224$ & $\$ 293$ & 20.0 & $\$ 45$ & $\$ 59$ \\
\hline$\$ 7,000$ to $\$ 25,000$ & 47.1 & 306 & 400 & 22 & 68 & 89 \\
\hline$\$ 25,000$ to $\$ 100,000$ & 15.6 & 101 & 133 & 51 & 52 & 69 \\
\hline$\$ 100,000$ and over & 2.9 & 19 & 25 & 82.5 & 16 & 21 \\
\hline Total & 100.0 & 650 & 850 & - & 201 & 238 \\
\hline
\end{tabular}

$1040 \mathrm{~A}$ and $1040 \mathrm{~W}$ returns, on which underreporting could very well be more pronounced, were excluded. For another, some 1099 returns may not have been filed, and hence no indication of underreporting would be uncovered. This could be a danger, particularly in small, closely held corporations. Moreover, the Survey did not cover foreign dividends on which underreporting might be greater because no information returns are filed. Finally, for about 16 per cent of the sample it was impossible to match 1040 returns and information returns. To the extent that this represented a failure to file, the Survey overstates the degree of reporting. There are, then, reasons for thinking that the Survey may have understated the gap, but there is no way of determining if it actually did and how much.

On the other hand, the unaudited Survey showed a 9 per cent gap; the audited Survey only a 5 per cent gap. Three points of this fourpercentage-point decline can be explained by dividends reported under other headings on form 1040 . We made no adjustment for this possibility; on this score, our measure of the gap tends to be too large. Against this should be put an item not taken account of by our method-other income reported as dividends, for instance, saving and loan "dividends" which are not in our aggregate dividend totals, but which might be reported as dividends on tax returns.

What follows from all this is not clear. In general, the Survey results do suggest that our measure overstates the gap, but not by as much as the difference between our 10 per cent and the Survey's 5 per cent. We have, then, this additional caution which, unavoidably, could not be worked into the text, because the Survey results came too late.

It is hoped the future surveys, focused more directly on underreporting, will permit a more precise statement on the size of the gap. 